EPJ Web of Conferences 22, 00011 (2012)

DOI: $10.1051 /$ epjconf/20122200011

(C) Owned by the authors, published by EDP Sciences, 2012

\title{
Conjugation and co-representation analysis of magnetic structures
}

\author{
J. Schweizer \\ INACISPSMS/Magnétisme et Diffraction Neutronique, CEA-Grenoble
}

\section{SUMMARY OF THE PREVIOUS CHAPTERS: THE REPRESENTATION THEORY OF MAGNETIC STRUCTURES [1]}

A magnetic structure is essentially described by its propagation vector $\mathbf{k}$, which relates the way the arrangement of atomic moments propagates from the primitive cell to the other cells of the crystal. The vector $\mathbf{k}$, which minimizes the magnetic energy, is generally determined in a neutron scattering experiment by indexing the magnetic reflections. The other elements which describe the magnetic structure, are, inside a unit cell, the mutual arrangement of the magnetic moments and the direction of these moments. These pieces of information are also obtained experimentally from the intensities of the magnetic reflections. However, once the propagation vector $\mathbf{k}$ is known, symmetry considerations with the help of group theory usually reduce the number of possible solutions.

As the magnetic moments are periodically arranged, they can be decomposed in their Fourier components $\mathbf{s}_{\mathbf{j}}^{\mathbf{k}}$ :

$$
\mathbf{m}_{\mathbf{j}}(\mathbf{R})=\sum_{\mathbf{k}} \mathbf{s}_{\mathbf{j}}^{\mathbf{k}} \mathrm{e}^{-\mathrm{ikR}}
$$

where $\mathbf{m}_{\mathbf{j}}(\mathbf{R})$ is the magnetic moment of the $\mathrm{j}^{\text {th }}$ magnetic atom of the cell, the origin of which being caracterized by the coordinate $\mathbf{R}$. The sum $\sum_{\mathbf{k}}$ is over different equivalent $\mathbf{k}$ vectors deduced one from the other by the symmetry elements of the crystal point group (the star of $\mathbf{k}$ vectors).

In order to sort the magnetic structures which are compatible with the crystal symmetries, one chooses, as explained in the former chapters [1] one particular $\mathbf{k}$ vector of the star of $\mathbf{k}$ vectors, which defines the "little group" $\mathrm{G}_{\mathrm{k}}$ (or "group of vector k"), the subgroup of the space group G which contains all the symmetry operators of $\mathrm{G}$ which keep the propagation vector $\mathbf{k}$ unchanged. Inside this little group $\mathrm{G}_{\mathrm{k}}$, one writes down the "natural" representation, that is the set of matrices which represent how the operators $\mathrm{h}_{i}$ of $\mathrm{G}_{\mathrm{k}}$ transform the components $\mathrm{s}_{\mathrm{j}, \alpha}^{\mathrm{k}}\left(\alpha\right.$ for $\mathrm{x}, \mathrm{y}$ or $\mathrm{z}$ ) of the Fourier components $\mathbf{s}_{\mathrm{j}}^{\mathbf{k}}$. The natural representation is of dimension $3 n$ if $n$ is the number of magnetic atoms in the primitive cell. This natural representation is then reduced into the irreducible representations by a change of basis vectors, the new basis vector $\mathbf{E}_{v}^{\mathbf{p}}$ corresponding to the irreducible representation $\tau_{v}$ of the little group $\mathrm{G}_{\mathrm{k}}$. The Landau theory of second order transitions guarantees that if one builds a magnetic structure according to formula (1), with basis vectors $\mathbf{E}_{v}^{\mathbf{p}}$ belonging to a same irreducible representation $\tau_{v}\left(\mathbf{s}^{\mathbf{k}}=\sum_{\mathbf{p}} \lambda_{v}^{\mathbf{p}} \mathbf{E}_{v}^{\mathbf{p}}\right)$, the magnetic energy:

$$
\mathrm{F}=\sum_{\mathrm{j}, \mathrm{j}^{\prime}} \sum_{\alpha, \beta} \mathrm{J}_{\mathrm{jj} j^{\prime} \alpha \beta}(\mathbf{k}) \mathrm{s}_{\mathrm{j} \alpha}^{\mathrm{k}} \mathrm{s}_{\mathrm{j}^{\prime} \beta}^{-\mathrm{k}}
$$

would remain unchanged under all the symmetry operations of the space group, operations which act on the propagation vector $\mathrm{k}$, on the exchange integrals $\mathrm{J}(\mathrm{k})$ and on the Fourier components $\mathbf{s}_{\mathrm{j}}^{\mathrm{k}}$. 
Formula (1) corresponds to a multi-k magnetic structure in that sense that the magnetic moment is a sum of Fourier components $\mathbf{s}_{\mathrm{j}}^{\mathrm{k}}$ belonging to different $\mathbf{k}$ vectors of the star of $\mathbf{k}$ vectors ${ }^{1}$.

A special attention must be brought to propagation vector $\mathbf{k}^{\prime}=-\mathbf{k}$.

On the first hand $\mathbf{m}_{\mathbf{j}}(\mathbf{R})$ is a real pseudovector and therefore $\mathbf{s}_{\mathbf{j}}^{-\mathbf{k}}=\left(\mathbf{s}_{\mathbf{j}}^{\mathbf{k}}\right)^{*}$. Even in the cases where vector $\mathbf{k}^{\prime}=\mathbf{- k}$ is not present in the star of vector $\mathbf{k}$, a complex conjugate term has to be added, and formula (1) should rather be written:

$$
\mathbf{m}_{\mathbf{j}}(\mathbf{R})=\sum_{\mathbf{k}}\left(\mathbf{s}_{\mathbf{j}}^{\mathbf{k}} \mathrm{e}^{-\mathrm{i} \mathbf{k} \mathbf{R}}+\left(\mathbf{s}_{\mathbf{j}}^{\mathbf{k}}\right)^{*} \mathrm{e}^{+\mathrm{ik \mathbf {R }}}\right)
$$

On the second hand, when $\mathbf{k}^{\prime}=-\mathbf{k}$ is present in the star of $\mathbf{k}$ vectors, one feels intuitively that excluding from the little group $G_{k}$ all the symmetry operations which transform $\mathbf{k}$ in $-\mathbf{k}$ results in a loss of information, even if the $-\mathbf{k}$ propagation vector is reintroduced at the end of the process when applying formula $\left(1^{\prime}\right)$ to recover the real magnetic moments.

It is the aim of this chapter to show how it is possible to take advantage of the existing symmetry operations which transform $\mathbf{k}$ in $-\mathbf{k}$ in the symmetry analysis of the magnetic structures. This has already been done by Bertaut [2], Rossat Mignod [3] and Schweizer [4] who used a symmetry operator "time inversion" to do it. Here, we will make use of the operator "conjugation" and take advantage of the Wigner corepresentations instead of the usual representations of the group theory. A working example will be treated in detail to show how it works and other examples will underline the interest of the method. Finally, the relation between the conjugation method adopted here and the time inversion method used earlier will be discussed.

\section{TAKING ADVANTAGE OF THE CONJUGATION: THE MAGNETIC LITTLE GROUP}

Let us consider the case where vector $\mathbf{k}^{\prime}=-\mathbf{k}$ is present in the star of vectors $\mathbf{k}$. That means that among the operators $h_{i}$ of the space group $G$, there are operators of type $h_{0}$ such that $h_{0} \mathbf{k}=-\mathbf{k}$. Let us for instance consider the simplest of these operators, inversion $\overline{1}=\mathrm{h}_{25}$ according to Kovalev notations [5], which reverses $\mathbf{k}$ but has no action on the magnetic moments. When such an operator is applied to the equation of an helix:

$$
\mathbf{m}(\mathbf{R})=(\mathbf{u}+\mathrm{iv}) \mathrm{e}^{-\mathrm{ikR}}+(\mathbf{u}-\mathrm{iv}) \mathrm{e}^{+\mathrm{ikR}}
$$

it transforms it in the equation of an helix of the opposite chirality:

$$
\overline{1} \mathbf{m}(\mathbf{R})=\overline{1}\left[(\mathbf{u}+\mathbf{i} \mathbf{v}) \mathrm{e}^{-i \mathbf{k R}}+(\mathbf{u}-\mathbf{i v}) \mathrm{e}^{+i \mathbf{k R}}\right]=(\mathbf{u}+\mathbf{i v}) \mathrm{e}^{+i \mathbf{k R}}+(\mathbf{u}-\mathbf{i v}) \mathrm{e}^{-i \mathbf{k R}}
$$

Let us now consider the operator conjugation $\mathrm{C}$. When applied to the magnetic energy represented by equation (2), it keeps it unchanged as the magnetic energy is real. When applied to our former helix equation (3), it conjugates the exponentials as does the inversion operator, but it conjugates also the magnetic moments, leaving in fine the magnetic helix unchanged:

$$
\mathbf{C m}(\mathbf{R})=\mathrm{C}\left[(\mathbf{u}+\mathrm{iv}) \mathrm{e}^{-\mathrm{i} \mathbf{k} \mathbf{R}}+(\mathbf{u}-\mathrm{iv}) \mathrm{e}^{+\mathrm{i} \mathbf{k} \mathbf{R}}\right]=(\mathbf{u}-\mathrm{i} \mathbf{v}) \mathrm{e}^{+\mathrm{i} \mathbf{k} \mathbf{R}}+(\mathbf{u}+\mathrm{i} \mathbf{v}) \mathrm{e}^{-\mathrm{i} \mathbf{k} \mathbf{R}}
$$

When applied to the magnetic structure described by equation $\left(1^{\prime}\right)$, it lets it unchanged, in spite of the fact that it conjugates all the elements:

$$
\mathrm{Cm}_{\mathbf{j}}(\mathbf{R})=\mathrm{C} \sum_{\mathbf{k}}\left(\mathbf{s}_{\mathbf{j}}^{\mathbf{k}} \mathrm{e}^{-i \mathbf{k} \mathbf{R}}+\left(\mathbf{s}_{\mathbf{j}}^{\mathbf{k}}\right)^{*} \mathrm{e}^{+i \mathbf{k} \mathbf{R}}\right)=\sum_{\mathbf{k}}\left(\left(\mathbf{s}_{\mathbf{j}}^{\mathbf{k}}\right)^{*} \mathrm{e}^{+i \mathbf{k} \mathbf{R}}+\mathbf{s}_{\mathbf{j}}^{\mathbf{k}} \mathrm{e}^{-i \mathbf{k R}}\right)=\mathbf{m}_{\mathbf{j}}(\mathbf{R})
$$

\footnotetext{
${ }^{1}$ Let us remind that this theory does not predict the phase differences which exist between the Fourier components $\mathbf{s}_{\mathrm{j}}^{\mathrm{k}}$ which enter this sum and which correspond to different vectors $\mathbf{k}$.
} 


\section{Contribution of Symmetries in Condensed Matter}

Now, if one associates operator inversion $\overline{1}$ and operator conjugation $\mathrm{C}$ and apply them together to the helix equation (3), one gets an helix of opposed chirality:

$$
\overline{1} \mathbf{C m}(\mathbf{R})=\overline{1} \mathrm{C}\left[(\mathbf{u}+\mathbf{i v}) \mathrm{e}^{-i \mathbf{k R}}+(\mathbf{u}-\mathbf{i v}) \mathrm{e}^{+\mathbf{i k R}}\right]=(\mathbf{u}-\mathbf{i v}) \mathrm{e}^{-\mathrm{ikR}}+(\mathbf{u}+\mathbf{i v}) \mathrm{e}^{+\mathbf{i k R}}
$$

where $(\mathbf{u}-\mathbf{i v})=(\mathbf{u}+\mathbf{i v})^{*}$ is associated to $\mathrm{e}^{-i \mathbf{k R}}$ and $(\mathbf{u}+\mathbf{i v})=(\mathbf{u}-\mathbf{i v})^{*}$ is associated to $\mathrm{e}^{+i \mathbf{k R}}$.

And, if we apply the same two operators to the magnetic structure described by equation $\left(1^{\prime}\right)$, we obtain the following moments:

$$
\overline{1} C \mathbf{m}_{\mathbf{j}}(\mathbf{R})=\overline{1} C \sum_{\mathbf{k}}\left(\mathbf{s}_{\mathbf{j}}^{\mathbf{k}} \mathrm{e}^{-\mathrm{i} \mathbf{k} \mathbf{R}}+\mathbf{s}_{\mathbf{j}}^{-\mathbf{k}} \mathrm{e}^{+i \mathbf{k} \mathbf{R}}\right)=\sum_{\mathbf{k}}\left(\mathbf{s}_{\mathbf{j}^{\prime}}^{* \mathbf{k}} \mathrm{e}^{-i \mathbf{k} \mathbf{R}}+\mathbf{s}_{\mathbf{j}^{\prime}}^{*-\mathbf{k}} \mathrm{e}^{+i \mathbf{k} \mathbf{R}}\right)
$$

where operator $\overline{1}$ changes atom $\mathrm{j}$ in atom $\mathrm{j}$, , but does not change the magnetic moments $\mathbf{s}$. In the resulting

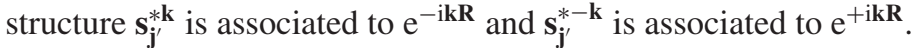

Finally, if one associates together an operator $\mathrm{h}_{0}$, which reverses $\mathbf{k}$, and operator conjugation $\mathrm{C}$, we get an operator a $\left(\mathrm{a}=\mathrm{h}_{0} \mathrm{C}=\mathrm{Ch}_{0}\right)$ for which the representation of a translation $\mathbf{T}$ is $\mathrm{e}^{-\mathrm{ikT}}$, the same exponential as for all the operators of the little group $G_{k}$, while it would have been $e^{+i k T}$ for each of these operators $\mathrm{h}_{0}$ or $\mathrm{C}$ taken separately.

$$
\mathrm{Ch}_{0} \mathbf{m}_{\mathbf{j}}(\mathbf{R})=\mathrm{Ch}_{0} \sum_{\mathbf{k}}\left(\mathbf{s}_{\mathbf{j}}^{\mathbf{k}} \mathrm{e}^{-\mathrm{i} \mathbf{k} \mathbf{R}}+\mathbf{s}_{\mathbf{j}}^{-\mathbf{k}} \mathrm{e}^{+\mathrm{i} \mathbf{k} \mathbf{R}}\right)=\sum_{k}\left(\mathbf{s}_{\mathbf{j}^{\prime}}^{* \mathbf{k}} \mathrm{e}^{-\mathrm{i} \mathbf{k} \mathbf{R}}+\mathbf{s}_{\mathbf{j}^{\prime}}^{*-\mathbf{k}} \mathrm{e}^{+i \mathbf{k} \mathbf{R}}\right)
$$

where operator $\mathrm{h}_{0}$ changes atom $\mathrm{j}$ in atom $\mathrm{j}^{\prime}$ and $\mathbf{s}_{\mathbf{j}}^{\mathbf{k}}$ in $\mathbf{s}_{\mathbf{j}^{\prime}}^{\mathbf{k}}$.

Attention: in the notations of this text, the $k$ index of the Fourier components $s_{j}^{k}$ represents the way these components behave under a translation. In particular, we make a difference between the conjugate $\left(s_{\mathbf{j}}^{\mathbf{k}}\right)^{*}=\mathbf{s}_{\mathbf{j}}^{-\mathbf{k}}$ of the Fourier component for which the representation of a translation $T$ is $\mathrm{e}^{+\mathrm{ikT}}$ and $\left(\mathrm{s}_{\mathbf{j}^{\prime}}^{*}\right)^{\mathbf{k}}=\mathrm{s}_{\mathbf{j}^{\prime}}^{* k}$ for which the representation of the same translation remains $\mathrm{e}^{-\mathrm{ikT}}$. The action of the operator $\mathbf{a}=\mathbf{h}_{\mathbf{0}} \mathrm{C}=\mathrm{Ch}_{\mathbf{0}}$ on a Fourier component $s_{\mathbf{j}}^{\mathbf{k}}$ gives $\left(\mathrm{s}_{\mathbf{j}^{\prime}}^{*}\right)^{\mathrm{k}}=\mathrm{s}_{\mathbf{j}^{\prime}}^{* k}$ and not $\left(\mathbf{s}_{\mathbf{j}^{\prime}}^{\mathbf{k}}\right)^{*}=\mathbf{s}_{\mathbf{j}^{\prime}}^{-\mathbf{k}}$.

However there is a price to pay: operator $\mathrm{a}=\mathrm{h}_{0} \mathrm{C}=\mathrm{Ch}_{0}$ is antilinear $\left(\mathrm{a}(\lambda \mathbf{s})=\lambda^{*} \mathrm{a}(\mathbf{s})\right)$ while all the operators of the space group $\mathrm{G}$ are linear $(\mathrm{h}(\lambda \mathbf{s})=\lambda \mathrm{h}(\mathbf{s}))$. This will induce some complications.

Following Bradley and Cracknell [6], we can now construct the magnetic group $\mathrm{M}$ which is composed, in the paramagnetic state, of all the operators of the space group $\mathrm{G}$ plus all these elements associated with the conjugation operators $\mathrm{C}\left(\mathrm{M}=\mathrm{G}+\mathrm{CG}\right.$ ). The magnetic little group $\mathrm{M}_{k}$ (or the magnetic group of vector $k$ ) consists now of all the operators of $G_{k}$ which keep unchanged the propagation vector $\mathbf{k}$ plus all the elements of $\mathrm{G}$ which reverse the vector $\mathbf{k}\left(\mathbf{k}^{\prime}=-\mathbf{k}\right)$, associated with the conjugation operator $\mathrm{C}$.

Practically, 3 different cases may occur:

1) There is no symmetry operator $h_{0}$ in the group $G$ which reverses the vector $\mathbf{k}$ ( $-\mathbf{k}$ does not belong to the star $\{\mathbf{k}\})$. We have then

$$
\mathrm{M}_{\mathrm{k}}=\mathrm{G}_{\mathrm{k}} \text { (Fedorov group) }
$$

2) $-\mathbf{k}$ belongs to the $\operatorname{star}\{\mathbf{k}\}$ but $-\mathbf{k}$ is equivalent to $\mathbf{k}$, which means that either $\mathbf{k}=0$ or $-\mathbf{k}=\mathbf{k}+\mathbf{K}$, where $\mathbf{K}$ is a reciprocal lattice vector. This leads to:

$$
\mathrm{M}_{\mathrm{k}}=\mathrm{G}_{\mathrm{k}}+\mathrm{CG}_{k}(\text { grey group})
$$

3) $-\mathbf{k}$ belongs to the $\operatorname{star}\{\mathbf{k}\}$ and is not equivalent to $\mathbf{k}$. One may choose in $\mathrm{G}$ an operator $\mathrm{h}_{0}$ which transforms $\mathbf{k}$ in $-\mathbf{k}$ which, associated with $\mathrm{C}$, constitutes the "reversing operator" $\mathrm{a}_{0}$ :

$$
\begin{aligned}
\mathrm{a}_{0} & =\mathrm{h}_{0} \mathrm{C}=\mathrm{Ch}_{0} \\
\mathrm{M}_{\mathrm{k}} & =\mathrm{G}_{\mathrm{k}}+\mathrm{a}_{0} \mathrm{G}_{\mathrm{k}} \text { (black and white group) }
\end{aligned}
$$


In these two last cases, the number of elements in $\mathrm{M}_{\mathrm{k}}$ is the double of the number of elements in $\mathrm{G}_{\mathrm{k}}$. As these elements are linear and antilinear operators, it is not possible to use the theory of representations as it stands. One has to use the theory of co-representations. We shall treat these two cases (2) and (3) together, considering for case (2) that $\mathrm{a}_{0}=\mathrm{eC}$, e being the operator identity.

\section{LINEAR AND ANTILINEAR OPERATORS: THE WIGNER CO-REPRESENTATIONS}

The theory of co-representations has been developed by Wigner [7] for groups including linear operators $\mathrm{h}_{i}$ and antilinear operators $\mathrm{a}_{\mathrm{i}}$ :

$-\mathrm{h}_{\mathrm{i}}$ transforms a vector $\mathbf{s}_{\mathrm{j}}^{\mathrm{k}}$ in a vector of type $\mathbf{s}_{\mathrm{j}^{\prime}}^{\mathrm{k}}$ and a vector $\mathbf{s}_{\mathrm{j}}^{* \mathrm{k}}$ in a vector of type $\mathbf{s}_{\mathrm{j}^{\prime}}^{* \mathrm{k}}$

- $\mathrm{a}_{\mathrm{i}}$ transforms a vector $\mathbf{s}_{\mathrm{j}}^{\mathrm{k}}$ in a vector of type $\left(\mathbf{s}_{\mathrm{j}^{\prime}}^{*}\right)^{\mathrm{k}}=\mathbf{s}_{\mathrm{j}^{\prime}}^{* \mathrm{k}}$ and a vector $\mathbf{s}_{\mathrm{j}}^{* \mathrm{k}}$ in a vector of type $\left(\left(\mathbf{s}_{\mathrm{j}^{\prime}}^{*}\right)^{*}\right)^{\mathrm{k}}=\mathbf{s}_{\mathrm{j}^{\prime}}^{\mathrm{k}}$

Therefore, with the exception of the Fedorov magnetic group, the number of basis vectors on which the operators act is twice larger for $M_{k}$ than for $G_{k}$.

To see how it is possible to transform a representation the group $G_{k}$ in a co-representation of the group $\mathrm{M}_{\mathrm{k}}$, with twice the number of basis vectors, let us first check what is the action of a linear operator $\mathrm{h}_{i}$ on a basis vector of type $\mathbf{s}_{\mathrm{j}^{\prime}}^{* \mathrm{k}}$.

Let us remind the following relations for the reversing operator $\mathrm{a}_{0}$ :

$$
\begin{aligned}
& \mathrm{a}_{0} \mathbf{s}_{\mathrm{j}}^{\mathrm{k}}=\mathbf{s}_{\mathrm{j}^{\prime}}^{* \mathrm{k}} \\
& \mathrm{a}_{0} \mathbf{s}_{\mathrm{j}}^{* \mathrm{k}}=\mathbf{s}_{\mathrm{j}^{\prime}}^{\mathrm{k}}
\end{aligned}
$$

all these vectors transforming with a coefficient $\mathrm{e}^{-\mathrm{ik \mathbf {T }}}$ under a translation $\mathbf{T}$.

If $\Delta\left(h_{i}\right)$ is a representation of the little group $G_{k}$, one can write:

$$
\begin{aligned}
h_{i} s_{j^{\prime}}^{* k} & =h_{i} a_{0} s_{j}^{k}=a_{0}\left(a_{0}^{-1} h_{i} a_{0}\right) s_{j}^{k}=a_{0} \Delta\left(a_{0}^{-1} h_{i} a_{0}\right) s_{j}^{k} \\
& =\Delta^{*}\left(a_{0}^{-1} h_{i} a_{0}\right) a_{0} s_{j}^{k}=\Delta^{*}\left(a_{0}^{-1} h_{i} a_{0}\right) s_{j^{\prime}}^{* k}
\end{aligned}
$$

because $\mathrm{a}_{0}^{-1} \mathrm{~h}_{\mathrm{i}} \mathrm{a}_{0}$ belongs to $\mathrm{G}_{\mathrm{k}}$ and also because $\mathrm{a}_{0}$ is antilinear.

Therefore:

$$
\mathrm{h}_{\mathrm{i}}\left(\begin{array}{ll}
\mathbf{s}_{\mathrm{j}}^{\mathrm{k}} & \mathbf{s}_{\mathrm{j}^{\prime}}^{* \mathrm{k}}
\end{array}\right)=\left(\begin{array}{ll}
\mathbf{s}_{\mathrm{j}}^{\mathrm{k}} & \mathbf{s}_{\mathrm{j}^{\prime}}^{* \mathrm{k}}
\end{array}\right)\left(\begin{array}{cc}
\Delta\left(\mathrm{h}_{\mathrm{i}}\right) & 0 \\
0 & \Delta^{*}\left(\mathrm{a}_{0}^{-1} \mathrm{~h}_{\mathrm{i}} \mathrm{a}_{0}\right)
\end{array}\right)
$$

Let us examine now the action of an antilinear operator $\mathrm{a}_{i}$ on a basis vector of type $\mathbf{s}_{\mathrm{j}}^{\mathrm{k}}$ :

$$
\begin{aligned}
\mathrm{a}_{\mathrm{i}} \mathbf{s}_{\mathrm{j}}^{\mathrm{k}} & =\mathrm{a}_{0} \mathrm{~h}_{\mathrm{i}} \mathbf{s}_{\mathrm{j}}^{\mathrm{k}}=\mathrm{a}_{0} \Delta\left(\mathrm{h}_{\mathrm{i}}\right) \mathbf{s}_{\mathrm{j}}^{\mathrm{k}} \\
& =\Delta^{*}\left(\mathrm{~h}_{\mathrm{i}}\right) \mathrm{a}_{0} \mathbf{s}_{\mathrm{j}}^{\mathrm{k}}=\Delta^{*}\left(\mathrm{a}_{0}^{-1} \mathrm{a}_{\mathrm{i}}\right) \mathbf{s}_{\mathrm{j}^{\prime}}^{* \mathrm{k}}
\end{aligned}
$$

and on a basis vector of type $\mathbf{s}_{\mathrm{j}^{\prime}}^{* \mathrm{k}}$ :

$$
\mathrm{a}_{\mathrm{i}} \mathrm{s}_{\mathrm{j}^{\prime}}^{* \mathrm{k}}=\mathrm{a}_{\mathrm{i}} \mathrm{a}_{0} \mathrm{~s}_{\mathrm{j}}^{\mathrm{k}}=\Delta\left(\mathrm{a}_{\mathrm{i}} \mathrm{a}_{0}\right) \mathbf{s}_{\mathrm{j}}^{\mathrm{k}}
$$

Hence, with a summation on the first index of the matrix elements:

$$
\mathrm{a}_{\mathrm{i}}\left(\mathbf{s}_{\mathrm{j}}^{\mathrm{k}} \mathbf{s}_{\mathrm{j}^{\prime}}^{* \mathrm{k}}\right)=\left(\begin{array}{ll}
\mathbf{s}_{\mathrm{j}}^{\mathrm{k}} & \mathbf{s}_{\mathrm{j}^{\prime}}^{* \mathrm{k}}
\end{array}\right)\left(\begin{array}{cc}
0 & \Delta\left(\mathrm{a}_{\mathrm{i}} \mathrm{a}_{0}\right) \\
\Delta^{*}\left(\mathrm{a}_{0}^{-1} \mathrm{a}_{\mathrm{i}}\right) & 0
\end{array}\right)
$$

The set of matrices (11) and (12) is the co-representation of $\mathrm{M}_{\mathrm{k}}$ derived from the representation $\Delta$ of $\mathrm{G}_{\mathrm{k}}$, which we denote $\mathrm{c} \Delta$. They do not obey the usual relation for a representation:

$$
\Delta(\mathrm{R}) \Delta(\mathrm{S})=\Delta(\mathrm{RS})
$$


but they obey a set of relations which depend whether the first matrix represents a linear or an antilinear operator:

$$
\begin{aligned}
& \mathrm{c} \Delta\left(\mathrm{h}_{\mathrm{i}}\right) \mathrm{c} \Delta\left(\mathrm{h}_{\mathrm{j}}\right)=\mathrm{c} \Delta\left(\mathrm{h}_{\mathrm{i}} \mathrm{h}_{\mathrm{j}}\right) \\
& \mathrm{c} \Delta\left(\mathrm{h}_{\mathrm{i}}\right) \mathrm{c} \Delta\left(\mathrm{a}_{\mathrm{j}}\right)=\mathrm{c} \Delta\left(\mathrm{h}_{\mathrm{i}} \mathrm{a}_{\mathrm{j}}\right) \\
& \mathrm{c} \Delta\left(\mathrm{a}_{\mathrm{i}}\right) \mathrm{c} \Delta^{*}\left(\mathrm{~h}_{\mathrm{j}}\right)=\mathrm{c} \Delta\left(\mathrm{a}_{\mathrm{i}} \mathrm{h}_{\mathrm{j}}\right) \\
& \mathrm{c} \Delta\left(\mathrm{a}_{\mathrm{i}}\right) \mathrm{c} \Delta^{*}\left(\mathrm{a}_{\mathrm{j}}\right)=\mathrm{c} \Delta\left(\mathrm{a}_{\mathrm{i}} \mathrm{a}_{\mathrm{j}}\right)
\end{aligned}
$$

\section{FROM THE NATURAL REPRESENTATION TO THE NATURAL CO-REPRESENTATION}

The vectors "Fourier components" $\mathbf{s}_{\mathbf{j}}^{\mathbf{k}}(\mathrm{j}=1,2, \ldots \mathrm{n})$ of the magnetic moments are decomposed along the 3 directions $\mathbf{a}, \mathbf{b}, \mathbf{c}$ of the unit cell in the following way:

$$
\begin{gathered}
\mathbf{s}_{1}^{\mathrm{k}}=\mathrm{s}_{1 \mathrm{x}}^{\mathrm{k}} \mathbf{e}_{\mathrm{x}}^{\mathrm{k}}+\mathrm{s}_{1 \mathrm{y}}^{\mathrm{k}} \mathbf{e}_{\mathrm{y}}^{\mathrm{k}}+\mathrm{s}_{1 \mathrm{z}}^{\mathrm{k}} \mathbf{e}_{\mathrm{z}}^{\mathrm{k}} \\
\mathbf{s}_{2}^{\mathrm{k}}=\mathrm{s}_{2 \mathrm{x}}^{\mathrm{k}} \mathbf{e}_{\mathrm{x}}^{\mathrm{k}}+\mathrm{s}_{2 \mathrm{y}}^{\mathrm{k}} \mathbf{e}_{\mathrm{y}}^{\mathrm{k}}+\mathrm{s}_{2 \mathrm{z}}^{\mathrm{k}} \mathbf{e}_{\mathrm{z}}^{\mathrm{k}} \\
\ldots \ldots \ldots \ldots \ldots \ldots \ldots \ldots \ldots \ldots \ldots \ldots \ldots \ldots \ldots \ldots \\
\mathbf{s}_{\mathrm{j}}^{\mathrm{k}}=\mathrm{s}_{\mathrm{jx}}^{\mathrm{k}} \mathbf{e}_{\mathrm{x}}^{\mathrm{k}}+\mathrm{s}_{\mathrm{jy}}^{\mathrm{k}} \mathbf{e}_{\mathrm{y}}^{\mathrm{k}}+\mathrm{s}_{\mathrm{jz}}^{\mathrm{k}} \mathbf{e}_{\mathrm{z}}^{\mathrm{k}}
\end{gathered}
$$

where the $s_{j \alpha}^{\mathrm{k}}$ are the coordinates of the vectors $\mathbf{s}_{\mathrm{j}}^{\mathrm{k}}$ and the $\mathbf{e}_{\alpha}^{\mathrm{k}}$ are the unitary vectors along axes $\mathbf{a}, \mathbf{b}$ and $\mathbf{c}$ of the cell. But one may also consider the $\mathrm{s}_{\mathrm{j} \alpha}^{\mathrm{k}}$ as the coordinates of a $3 \mathrm{n}$ dimension vector in the following way:

$$
\begin{gathered}
\mathbf{s}_{1}^{\mathrm{k}}=\mathrm{s}_{1 \mathrm{x}}^{\mathrm{k}} \mathbf{e}_{1 \mathrm{x}}^{\mathrm{k}}+\mathrm{s}_{1 \mathrm{y}}^{\mathrm{k}} \mathbf{e}_{1 \mathrm{y}}^{\mathrm{k}}+\mathrm{s}_{1 \mathrm{z}}^{\mathrm{k}} \mathbf{e}_{1 \mathrm{z}}^{\mathrm{k}} \\
\mathbf{s}_{2}^{\mathrm{k}}=\mathrm{s}_{2 \mathrm{x}}^{\mathrm{k}} \mathbf{e}_{2 \mathrm{x}}^{\mathrm{k}}+\mathrm{s}_{2 \mathrm{y}}^{\mathrm{k}} \mathbf{e}_{2 \mathrm{y}}^{\mathrm{k}}+\mathrm{s}_{2 \mathrm{z}}^{\mathrm{k}} \mathbf{e}_{2 \mathrm{z}}^{\mathrm{k}} \\
\ldots \ldots \ldots \ldots \ldots \ldots \ldots \cdots \cdots \cdots \cdots \cdots \cdots \cdots \cdots \cdots \\
\mathbf{s}_{\mathrm{j}}^{\mathrm{k}}=\mathrm{s}_{\mathrm{jx}}^{\mathrm{k}} \mathbf{e}_{\mathrm{jx}}^{\mathrm{k}}+\mathrm{s}_{\mathrm{jy}}^{\mathrm{k}} \mathbf{e}_{\mathrm{jy}}^{\mathrm{k}}+\mathrm{s}_{\mathrm{jz}}^{\mathrm{k}} \mathbf{e}_{\mathrm{jz}}^{\mathrm{k}}
\end{gathered}
$$

where the $\mathbf{e}_{\mathrm{j} \alpha}^{\mathrm{k}}$ are the unit vectors dedicated to atom $\mathrm{j}$, along the direction $\alpha$ of the cell.

The "natural representation" is a set of matrices which describe the action of the symmetry operators of the group $\mathrm{G}_{\mathrm{k}}$. This action may be considered in two different ways:

- either the operators keep the basis vectors unchanged an act on the coordinates $\mathrm{s}_{\mathrm{j} \alpha}^{\mathrm{k}}$ (active operators)

- or the operators keep the representative point fixed but moves the basis vectors $\mathbf{e}_{\mathrm{j} \alpha}^{\mathrm{k}}$ (passive operators).

According to the choice which is made, the corresponding "natural representation" is written in a different way.

Coming now to the co-representations of the little groups, they include antilinear operators ("grey" groups or "black and white" groups) and we have twice more coordinates, the $s_{j \alpha}^{\mathrm{k}}$ and the $s_{j \alpha}^{* k}$ that we can consider now as the coordinates of a 6 dimension vector in the following way:

$$
\begin{gathered}
\mathbf{s}_{1}^{\mathrm{k}}=\mathrm{s}_{1 \mathrm{x}}^{\mathrm{k}} \mathbf{e}_{1 \mathrm{x}}^{\mathrm{k}}+\mathrm{s}_{1 \mathrm{y}}^{\mathrm{k}} \mathbf{e}_{1 \mathrm{y}}^{\mathrm{k}}+\mathrm{s}_{1 \mathrm{z}}^{\mathrm{k}} \mathbf{e}_{1 \mathrm{z}}^{\mathrm{k}} \\
\mathbf{s}_{2}^{\mathrm{k}}=\mathrm{s}_{2 \mathrm{x}}^{\mathrm{k}} \mathbf{e}_{2 \mathrm{x}}^{\mathrm{k}}+s_{2 \mathrm{y}}^{\mathrm{k}} \mathbf{e}_{2 \mathrm{y}}^{\mathrm{k}}+\mathrm{s}_{2 \mathrm{z}}^{\mathrm{k}} \mathbf{e}_{2 \mathrm{z}}^{\mathrm{k}} \\
\ldots \ldots \ldots \ldots \ldots \ldots \ldots \ldots \ldots \ldots \ldots \ldots \ldots \ldots \ldots \ldots \ldots \\
\mathbf{s}_{\mathrm{j}}^{\mathrm{k}}=\mathrm{s}_{\mathrm{jx}}^{\mathrm{k}} \mathbf{e}_{\mathrm{jx}}^{\mathrm{k}}+\mathrm{s}_{\mathrm{jy}}^{\mathrm{k}} \mathbf{e}_{\mathrm{jy}}^{\mathrm{k}}+\mathrm{s}_{\mathrm{jz}}^{\mathrm{k}} \mathbf{e}_{\mathrm{jz}}^{\mathrm{k}}
\end{gathered}
$$




$$
\begin{aligned}
& \mathbf{s}_{1}^{* \mathrm{k}}=\mathrm{s}_{1 \mathrm{x}}^{* \mathrm{k}} \mathbf{e}_{1 \mathrm{x}}^{* \mathrm{k}}+\mathrm{s}_{1 \mathrm{y}}^{* \mathrm{k}} \mathbf{e}_{1 y}^{* \mathrm{k}}+\mathrm{s}_{1 \mathrm{z}}^{* \mathrm{k}} \mathbf{e}_{1 \mathrm{z}}^{* \mathrm{k}} \\
& \mathbf{s}_{2}^{* \mathrm{k}}=\mathrm{s}_{2 \mathrm{x}}^{* \mathrm{k}} \mathbf{e}_{2 \mathrm{x}}^{* \mathrm{k}}+s_{2 \mathrm{y}}^{* \mathrm{k}} \mathbf{e}_{2 y}^{* \mathrm{k}}+\mathrm{s}_{2 \mathrm{z}}^{* \mathrm{k}} \mathbf{e}_{2 \mathrm{z}}^{* \mathrm{k}} \\
& \mathbf{s}_{\mathrm{j}}^{* \mathrm{k}}=\mathrm{s}_{\mathrm{jx}}^{* \mathrm{k}} \mathbf{e}_{\mathrm{jx}}^{* \mathrm{k}}+\mathrm{s}_{\mathrm{jy}}^{* \mathrm{k}} \mathbf{e}_{\mathrm{j} y}^{* \mathrm{k}}+\mathrm{s}_{\mathrm{jz}}^{* \mathrm{k}} \mathbf{e}_{\mathrm{j} \mathrm{z}}^{* \mathrm{k}}
\end{aligned}
$$

the vectors $\mathbf{e}_{\mathrm{j} \alpha}^{\mathrm{k}}$ and $\mathbf{e}_{\mathrm{j} \alpha}^{* \mathrm{k}}$ being the unitary basis vectors corresponding to atom $\mathrm{j}$ in this $6 \mathrm{n}$-dimension space.

As for the natural representation, it is possible to write down a "natural co-representation" which represents the action of the different operators (linear and antilinear) on the 6n-dimension vector. And as for the natural representation, one can choose the action of the operators on the coordinates $s_{j \alpha}^{\mathrm{k}}$ and $\mathrm{s}_{\mathrm{j} \alpha}^{* \mathrm{k}}$ of the vector (active operators) or the action of the operators on the basis vectors $\mathbf{e}_{j \alpha}^{\mathrm{k}}$ and $\mathbf{e}_{j \alpha}^{* \mathrm{k}}$ (passive operators). Both approaches will be used in the following: active operators for the working example and passive operators for the other examples.

\section{THE IRREDUCIBLE CO-REPRESENTATIONS}

The recipe to build a co-representation from an irreducible representation $\tau_{v}$ of the little group $\mathrm{G}_{\mathrm{k}}$ is the same as that given above by matrices (11) and (12). However we are not guaranteed that such a co-representation is irreducible and sometimes it is not the case. This point is thoroughly explained in references [5-7]. There are 3 different cases depending on the value taken by the sum $\sum_{\mathrm{a}_{\mathrm{j}}} \chi\left(\mathrm{a}_{\mathrm{j}}^{2}\right)$, sum over all the antilinear operators $a_{j}$, noticing that the operators $a_{j}^{2}$ are of type $h$, which means linear operators. Let us note that this criterion is often called reality criterion as it is used to know whether an irreducible representation is real, pseudo-real or complex.

Case (a): $\sum_{\mathrm{a}_{\mathrm{j}}} \chi\left(\mathrm{a}_{\mathrm{j}}^{2}\right)=\mathrm{g}$, where $\mathrm{g}$ is the order of the little group $\mathrm{G}_{\mathrm{k}}$.

The co-representation obtained by the above recipe is reducible. From the irreducible representation $\tau_{\nu}$ one can build two irreducible co-representations $\mathrm{c} \tau_{\nu}^{+}$and $\mathrm{c} \tau_{\nu}^{-}$:

$$
\begin{gathered}
c \tau_{v}^{+}\left(\mathrm{h}_{\mathrm{i}}\right)=\tau_{v}\left(\mathrm{~h}_{\mathrm{i}}\right) \quad c \tau_{v}^{+}\left(\mathrm{a}_{\mathrm{j}}\right)=\tau_{v}\left(\mathrm{a}_{\mathrm{j}} \mathrm{a}_{0}^{-1}\right) \beta \\
\mathrm{c} \tau_{v}^{-}\left(\mathrm{h}_{\mathrm{i}}\right)=\tau_{v}\left(\mathrm{~h}_{\mathrm{i}}\right) \quad c \tau_{v}^{-}\left(\mathrm{a}_{\mathrm{j}}\right)=-\tau_{v}\left(\mathrm{a}_{\mathrm{j}} \mathrm{a}_{0}^{-1}\right) \beta
\end{gathered}
$$

As $\mathrm{a}_{\mathrm{j}} \mathrm{a}_{0}^{-1}$ is a linear operator $\tau_{\nu}\left(\mathrm{a}_{\mathrm{j}} \mathrm{a}_{0}^{-1}\right)$ is well defined. $\beta$ is an auxiliary matrix and such matrices are tabulated in reference [5].

The two irreducible co-representations $\mathrm{c} \tau_{v}^{+}$and $\mathrm{c} \tau_{v}^{-}$are equivalent and we shall show in the examples that the corresponding magnetic structures are the same.

Case (b): $\quad \sum_{\mathrm{a}_{\mathrm{j}}} \chi\left(\mathrm{a}_{\mathrm{j}}^{2}\right)=-\mathrm{g}$

The irreducible representation $\tau_{v}$ is transformed in an irreducible co-representations with an order twice larger:

$$
\mathrm{c} \tau_{v}\left(\mathrm{~h}_{\mathrm{i}}\right)=\left(\begin{array}{cc}
\tau_{v}\left(\mathrm{~h}_{\mathrm{i}}\right) & 0 \\
0 & \tau_{\nu}\left(\mathrm{h}_{\mathrm{i}}\right)
\end{array}\right) \quad \mathrm{c} \tau_{v}\left(\mathrm{a}_{\mathrm{j}}\right)=\left(\begin{array}{cc}
0 & -\tau_{v}\left(\mathrm{a}_{\mathrm{j}} \mathrm{a}_{0}^{-1}\right) \beta \\
\tau_{v}\left(\mathrm{a}_{\mathrm{j}} \mathrm{a}_{0}^{-1}\right) \beta & 0
\end{array}\right)
$$

also with an auxiliary matrix $\beta$ which is tabulated in [5].

Case (c): $\sum_{\mathrm{a}_{\mathrm{j}}} \chi\left(\mathrm{a}_{\mathrm{j}}^{2}\right)=0$

In this case it exists another irreducible representation of $\mathrm{G}_{\mathrm{k}}: \tau_{v^{\prime}}$ distinct from $\tau_{v}$ (with $\left.v^{\prime} \neq v\right)$, such as:

$$
\tau_{v^{\prime}}\left(\mathrm{h}_{\mathrm{i}}\right)=\left(\tau_{v}\left(\mathrm{a}_{0}^{-1} \mathrm{~h}_{\mathrm{i}} \mathrm{a}_{0}\right)\right)^{*}
$$




\section{Contribution of Symmetries in Condensed Matter}

These two conjugate irreducible representations $\tau_{v}$ and $\tau_{v^{\prime}}$ join together to give an irreducible representation $\mathrm{c} \tau_{v+v^{\prime}}$ of the magnetic little group $\mathrm{M}_{\mathrm{k}}$, with an order twice larger than the order of $\tau_{v}$ and $\tau_{v^{\prime}}$.

$$
\mathrm{c} \tau_{\nu+v^{\prime}}\left(\mathrm{h}_{\mathrm{i}}\right)=\left(\begin{array}{cc}
\tau_{v}\left(\mathrm{~h}_{\mathrm{i}}\right) & 0 \\
0 & \tau_{v^{\prime}}\left(\mathrm{h}_{\mathrm{i}}\right)
\end{array}\right) \quad \mathrm{c} \tau_{\nu+v^{\prime}}\left(\mathrm{a}_{\mathrm{j}}\right)=\left(\begin{array}{cc}
0 & \tau_{\nu}\left(\mathrm{a}_{\mathrm{j}} \mathrm{a}_{0}\right) \\
\tau_{v^{\prime}}\left(\mathrm{a}_{\mathrm{j}} \mathrm{a}_{0}^{-1}\right) & 0
\end{array}\right)
$$

The situation where the magnetic group is equivalent to the Fedorov group $\left(\mathrm{M}_{\mathrm{k}}=\mathrm{G}_{\mathrm{k}}\right)$ implies also, in a trivial way, the relation $\sum_{\mathrm{a}_{\mathrm{j}}} \chi\left(\mathrm{a}_{\mathrm{j}}^{2}\right)=0$, as the magnetic little group contains no antilinear operator of type $\mathrm{a}_{j}$. The vector $-\mathbf{k}$, though it does not belong to the star of vectors $\{\mathbf{k}\}$, is associated to vector $\mathbf{k}$ by the conjugation operator: there is no additional degeneracy inside the group $\mathrm{G}_{\mathrm{k}}$, but an extra degeneracy exists which associates, with the same magnetic energy, the Fourier component $\mathbf{s}_{\mathrm{j}}^{-\mathrm{k}}$ and $\mathbf{s}_{\mathrm{j}}^{\mathrm{k}}$ as mentioned above in relation $\left(1^{\prime}\right)$.

In practice, for all little groups $G_{k}$, that is for the 230 space groups and all the possible symmetries of the propagation vector $\mathrm{k}$, references [5] and [6] indicate whether the different irreducible representations of $\mathrm{G}_{\mathrm{k}}$ belong to case (a), (b) or (c). Furthermore, reference [5] gives also the auxiliary matrix $\beta$ when it is different from unity.

\section{A WORKING EXAMPLE: PrPtAl [8]}

\section{VI.1 Représentation analysis}

PrPtAl crystallizes in space group Pnma $\left(D_{2 h}^{16}\right) n^{\circ} 62$. This space group contains 8 rotation (rotationinversion) operators which are listed here according to Kovalev's notation [5] together with their action on the coordinates of a polar (real) vector.

\begin{tabular}{|l|l|l|l|}
\hline $\begin{array}{l}\text { Kovalev's } \\
\text { notation }\end{array}$ & $\begin{array}{l}\text { Action on } \\
\text { polar coordinates }\end{array}$ & $\begin{array}{c}\text { Kovalev's } \\
\text { notation }\end{array}$ & $\begin{array}{l}\text { Action on } \\
\text { polar coordinates }\end{array}$ \\
\hline $\mathrm{h}_{1}$ & $\mathrm{x}, \mathrm{y}, \mathrm{z}$ & $\mathrm{h}_{25}$ & $-\mathrm{x},-\mathrm{y},-\mathrm{z}$ \\
\hline $\mathrm{h}_{4}$ & $-\mathrm{x}+1 / 2,-\mathrm{y}, \mathrm{z}+1 / 2$ & $\mathrm{~h}_{28}=\mathrm{h}_{25} \mathrm{~h}_{4}$ & $\mathrm{x}-1 / 2, \mathrm{y},-\mathrm{z}-1 / 2$ \\
\hline $\mathrm{h}_{26}$ & $-\mathrm{x}+1 / 2, \mathrm{y}+1 / 2, \mathrm{z}+1 / 2$ & $\mathrm{~h}_{2}=\mathrm{h}_{25} \mathrm{~h}_{26}$ & $\mathrm{x}-1 / 2,-\mathrm{y}-1 / 2,-\mathrm{z}-1 / 2$ \\
\hline $\mathrm{h}_{27}$ & $\mathrm{x},-\mathrm{y}+1 / 2, \mathrm{z}$ & $\mathrm{h}_{3}=\mathrm{h}_{25} \mathrm{~h}_{27}$ & $-\mathrm{x}, \mathrm{y}-1 / 2,-\mathrm{z}$ \\
\hline
\end{tabular}

Compared to the International Tables, the signs of the fractional translations $1 / 2$ associated to coordinates $\mathrm{x}, \mathrm{y}$ or $\mathrm{z}$ of the operators $\mathrm{h}_{28}, \mathrm{~h}_{2}$ and $\mathrm{h}_{3}$ have been changed, in order to respect the operator relations of the third column.

There are 4 Pr atoms in the unit cell, and their coordinates are reported in the next table:

\begin{tabular}{|l|l|}
\hline Pr atom & International Tables \\
\hline $\operatorname{Pr}_{1}$ & $\mathrm{x}, 1 / 4, \mathrm{z}$ \\
\hline $\mathrm{Pr}_{2}$ & $-x+1 / 2,3 / 4, \mathrm{z}+1 / 2$ \\
\hline $\mathrm{Pr}_{3}$ & $-x, 3 / 4,-\mathrm{z}$ \\
\hline $\mathrm{Pr}_{4}$ & $\mathrm{x}+1 / 2,1 / 4,-\mathrm{z}+1 / 2$ \\
\hline
\end{tabular}

Below the Néel temperature, the $\operatorname{Pr}$ atoms order magnetically with a propagation vector $\mathbf{k}=\left(0,0, \mathrm{k}_{z}\right)$.

We write down the natural representation of the magnetic moments in this little group $\mathrm{G}_{\mathrm{k}}$. In this example, we choose to use the active operator approach and write down how the operators act on the coordinates $\mathrm{s}_{\mathrm{j} \alpha}^{\mathrm{k}}$, and later $\mathrm{s}_{\mathrm{j} \alpha}^{\mathrm{k}}$ of the magnetic moments. We shall do it in two substeps. First we write down how the 4 rotation (or rotation-inversion) operators of $G_{k}$ transform one Pr position in another $\operatorname{Pr}$ position. 
EPJ Web of Conferences

\begin{tabular}{|l|c|c|c|l|}
\hline Pr atom & $\begin{array}{c}\mathrm{h}_{1} \\
(\mathrm{x}, \mathrm{y}, \mathrm{z})\end{array}$ & $\begin{array}{c}\mathrm{h}_{4} \\
(-\mathrm{x}+1 / 2,-\mathrm{y}, \mathrm{z}+1 / 2)\end{array}$ & $\begin{array}{c}\mathrm{h}_{26} \\
(-\mathrm{x}+1 / 2, \mathrm{y}+1 / 2, \mathrm{z}+1 / 2)\end{array}$ & $\begin{array}{c}\mathrm{h}_{27} \\
(\mathrm{x},-\mathrm{y}+1 / 2, \mathrm{z})\end{array}$ \\
\hline $\operatorname{Pr}_{1}$ & $\operatorname{Pr}_{1}$ & $\operatorname{Pr}_{2}+[0,-1,0]$ & $\operatorname{Pr}_{2}$ & $\operatorname{Pr}_{1}$ \\
\hline $\operatorname{Pr}_{2}$ & $\operatorname{Pr}_{2}$ & $\operatorname{Pr}_{1}+[0,-1,1]$ & $\operatorname{Pr}_{1}+[0,1,1]$ & $\operatorname{Pr}_{2}+[0,-1,0]$ \\
\hline $\operatorname{Pr}_{3}$ & $\operatorname{Pr}_{3}$ & $\operatorname{Pr}_{4}+[0,-1,0]$ & $\operatorname{Pr}_{4}+[0,1,0]$ & $\operatorname{Pr}_{3}+[0,-1,0]$ \\
\hline $\operatorname{Pr}_{4}$ & $\operatorname{Pr}_{4}$ & $\operatorname{Pr}_{3}+[0,-1,1]$ & $\operatorname{Pr}_{3}+[0,0,1]$ & $\operatorname{Pr}_{4}$ \\
\hline
\end{tabular}

Then we write the action of the operators on the components of the magnetic moments, including the labels of the Pr positions. We have to remind here that we deal with pseudo-vectors (axial vectors): for $\mathrm{h}_{1}$ and $\mathrm{h}_{4}$ which are proper operators we take the same transformations as those reported in the International Tables; for $\mathrm{h}_{26}$ and $\mathrm{h}_{27}$ we change all the signs.

\begin{tabular}{|l|c|c|c|c|}
\hline Component & $\begin{array}{c}\mathrm{h}_{1} \\
(\mathrm{x}, \mathrm{y}, \mathrm{z})\end{array}$ & $\begin{array}{c}\mathrm{h}_{4} \\
(-\mathrm{x}+1 / 2,-\mathrm{y}, \mathrm{z}+1 / 2)\end{array}$ & $\begin{array}{c}\mathrm{h}_{26} \\
(-\mathrm{x}+1 / 2, \mathrm{y}+1 / 2, \mathrm{z}+1 / 2)\end{array}$ & $\begin{array}{c}\mathrm{h}_{27} \\
(\mathrm{x},-\mathrm{y}+1 / 2, \mathrm{z})\end{array}$ \\
\hline $\mathrm{s}_{1 \mathrm{x}}^{\mathrm{k}}$ & $\mathrm{s}_{1 \mathrm{x}}^{\mathrm{k}}$ & $-\mathrm{s}_{2 \mathrm{x}}^{\mathrm{k}}$ & $\mathrm{s}_{2 \mathrm{x}}^{\mathrm{k}}$ & $-\mathrm{s}_{1 \mathrm{x}}^{\mathrm{k}}$ \\
\hline $\mathrm{s}_{1 \mathrm{y}}^{\mathrm{k}}$ & $\mathrm{s}_{1 \mathrm{y}}^{\mathrm{k}}$ & $-\mathrm{s}_{2 \mathrm{y}}^{\mathrm{k}}$ & $-\mathrm{s}_{2 \mathrm{y}}^{\mathrm{k}}$ & $\mathrm{s}_{1 \mathrm{y}}^{\mathrm{k}}$ \\
\hline $\mathrm{s}_{1 \mathrm{z}}^{\mathrm{k}}$ & $\mathrm{s}_{1 \mathrm{z}}^{\mathrm{k}}$ & $\mathrm{s}_{2 \mathrm{z}}^{\mathrm{k}}$ & $-\mathrm{s}_{2 \mathrm{z}}^{\mathrm{k}}$ & $-\mathrm{s}_{1 \mathrm{z}}^{\mathrm{k}}$ \\
\hline $\mathrm{s}_{2 \mathrm{x}}^{\mathrm{k}}$ & $\mathrm{s}_{2 \mathrm{x}}^{\mathrm{k}}$ & $-\mathrm{s}_{1 \mathrm{x}}^{\mathrm{k}} \mathrm{a}^{-2}$ & $\mathrm{~s}_{1 \mathrm{x}}^{\mathrm{k}} \mathrm{a}^{-2}$ & $-\mathrm{s}_{2 \mathrm{x}}^{\mathrm{k}}$ \\
\hline $\mathrm{s}_{2 \mathrm{y}}^{\mathrm{k}}$ & $\mathrm{s}_{2 \mathrm{y}}^{\mathrm{k}}$ & $-\mathrm{s}_{1 \mathrm{y}}^{\mathrm{k}} \mathrm{a}^{-2}$ & $-\mathrm{s}_{1 \mathrm{y}}^{\mathrm{k}} \mathrm{a}^{-2}$ & $\mathrm{~s}_{2 \mathrm{y}}^{\mathrm{k}}$ \\
\hline $\mathrm{s}_{2 \mathrm{z}}^{\mathrm{k}}$ & $\mathrm{s}_{2 \mathrm{z}}^{\mathrm{k}}$ & $\mathrm{s}_{1 \mathrm{z}^{\mathrm{k}}} \mathrm{a}^{-2}$ & $-\mathrm{s}_{1 \mathrm{z}^{\mathrm{k}}} \mathrm{a}^{-2}$ & $-\mathrm{s}_{2 \mathrm{z}}$ \\
\hline $\mathrm{s}_{3 \mathrm{x}}^{\mathrm{k}}$ & $\mathrm{s}_{3 \mathrm{x}}^{\mathrm{k}}$ & $-\mathrm{s}_{4 \mathrm{x}}^{\mathrm{k}}$ & $\mathrm{s}_{4 \mathrm{x}}^{\mathrm{k}}$ & $-\mathrm{s}_{3 \mathrm{x}}$ \\
\hline $\mathrm{s}_{3 \mathrm{y}}^{\mathrm{k}}$ & $\mathrm{s}_{3 \mathrm{y}}^{\mathrm{k}}$ & $-\mathrm{s}_{4 \mathrm{y}}^{\mathrm{k}}$ & $-\mathrm{s}_{4 \mathrm{y}}^{\mathrm{k}}$ & $\mathrm{s}_{3 \mathrm{y}}^{\mathrm{k}}$ \\
\hline $\mathrm{s}_{3 \mathrm{z}}^{\mathrm{k}}$ & $\mathrm{s}_{3 \mathrm{z}}^{\mathrm{k}}$ & $\mathrm{s}_{4 \mathrm{z}}^{\mathrm{k}}$ & $-\mathrm{s}_{4 \mathrm{z}}^{\mathrm{k}}$ & $-\mathrm{s}_{3 \mathrm{z}}^{\mathrm{k}}$ \\
\hline $\mathrm{s}_{4 \mathrm{x}}^{\mathrm{k}}$ & $\mathrm{s}_{4 \mathrm{x}}^{\mathrm{k}}$ & $-\mathrm{s}_{3 \mathrm{x}}^{\mathrm{k}} \mathrm{a}^{-2}$ & $\mathrm{~s}_{3 \mathrm{x}}^{\mathrm{k}} \mathrm{a}^{-2}$ & $-\mathrm{s}_{4 \mathrm{x}}^{\mathrm{k}}$ \\
\hline $\mathrm{s}_{4 \mathrm{y}}^{\mathrm{k}}$ & $\mathrm{s}_{4 \mathrm{y}}^{\mathrm{k}}$ & $-\mathrm{s}_{3 \mathrm{y}}^{\mathrm{k}} \mathrm{a}^{-2}$ & $-\mathrm{s}_{3 \mathrm{y}}^{\mathrm{k}} \mathrm{a}^{-2}$ & $\mathrm{~s}_{4 \mathrm{y}}^{\mathrm{k}}$ \\
\hline $\mathrm{s}_{4 \mathrm{z}}^{\mathrm{k}}$ & $\mathrm{s}_{4 \mathrm{z}}^{\mathrm{k}}$ & $\mathrm{s}_{3 \mathrm{z}}^{\mathrm{k}} \mathrm{a}^{-2}$ & $-\mathrm{s}_{3 \mathrm{z}}^{\mathrm{k}} \mathrm{a}^{-2}$ & $-\mathrm{s}_{4 \mathrm{z}}^{\mathrm{k}}$ \\
\hline$\chi\left(\Gamma_{\mathrm{k}}\right)$ & 12 & 0 & 0 & -4 \\
\hline
\end{tabular}

The quantity $\mathrm{a}^{-2}=\mathrm{e}^{-2 \mathrm{i} \pi \mathrm{k}_{\mathrm{z}}}$ represents the translation $\mathbf{t}_{\mathrm{i}}$ to the next cell which occurs for some of the rotation (or rotation-inversion) operators.

We have written the characters of this natural representation $\Gamma_{\mathrm{k}}$. The writing of the 4 matrices $12 \mathrm{x}$ 12 of this representation is obvious but takes too much space. Moreover, it is not really necessary.

We shall now reduce this representation $\Gamma_{\mathrm{k}}$ in irreducible representations $\tau_{v}$ of the little group.

We take in Kovalev's text books [5] the following table for the loaded irreducible representations: There are all of order 1.

\begin{tabular}{|l|c|c|c|c|}
\hline Loaded irrep & $\begin{array}{c}\mathrm{h}_{1} \\
(\mathrm{x}, \mathrm{y}, \mathrm{z})\end{array}$ & $\begin{array}{c}\mathrm{h}_{4} \\
(-\mathrm{x}+1 / 2,-\mathrm{y}, \mathrm{z}+1 / 2)\end{array}$ & $\begin{array}{c}\mathrm{h}_{26} \\
(-\mathrm{x}+1 / 2, \mathrm{y}+1 / 2, \mathrm{z}+1 / 2)\end{array}$ & $\begin{array}{c}\mathrm{h}_{27} \\
(\mathrm{x},-\mathrm{y}+1 / 2, \mathrm{z})\end{array}$ \\
\hline$\hat{\tau}_{1}$ & 1 & 1 & 1 & 1 \\
\hline$\hat{\tau}_{2}$ & 1 & 1 & -1 & -1 \\
\hline$\hat{\tau}_{3}$ & 1 & -1 & 1 & -1 \\
\hline$\hat{\tau}_{4}$ & 1 & -1 & -1 & 1 \\
\hline
\end{tabular}

And we find the irreducible representations by applying $\tau_{v}=\hat{\tau}_{\nu} \mathrm{e}^{-\mathrm{i} \mathbf{k} \cdot \mathbf{v}_{\mathrm{i}}}$ where $\mathbf{v}_{\mathrm{i}}$ are the fractional translations of the operators $\left(\mathrm{h}_{\mathrm{i}} \mid \mathbf{v}_{\mathrm{i}}\right)$ in the non symmorphic groups. 


\section{Contribution of Symmetries in Condensed Matter}

\begin{tabular}{|c|c|c|c|c|}
\hline Irrep & $\begin{array}{c}\mathrm{h}_{1} \\
(\mathrm{x}, \mathrm{y}, \mathrm{z})\end{array}$ & $\begin{array}{c}\mathrm{h}_{4} \\
(-\mathrm{x}+1 / 2,-\mathrm{y}, \mathrm{z}+1 / 2)\end{array}$ & $\begin{array}{c}\mathrm{h}_{26} \\
(-\mathrm{x}+1 / 2, \mathrm{y}+1 / 2, \mathrm{z}+1 / 2)\end{array}$ & $\begin{array}{c}\mathrm{h}_{27} \\
(\mathrm{x},-\mathrm{y}+1 / 2, \mathrm{z})\end{array}$ \\
\hline$\tau_{1}$ & 1 & $\mathrm{a}^{-1}$ & $\mathrm{a}^{-1}$ & 1 \\
\hline$\tau_{2}$ & 1 & $\mathrm{a}^{-1}$ & $-\mathrm{a}^{-1}$ & -1 \\
\hline$\tau_{3}$ & 1 & $-\mathrm{a}^{-1}$ & $\mathrm{a}^{-1}$ & -1 \\
\hline$\tau_{4}$ & 1 & $-\mathrm{a}^{-1}$ & $-\mathrm{a}^{-1}$ & 1 \\
\hline
\end{tabular}

With $\mathrm{a}^{-1}=\mathrm{e}^{-\mathrm{i} \pi \mathrm{k}_{\mathrm{z}}}$.

We now reduce the natural representations $\Gamma_{\mathrm{k}}$ in its irreducible representations $\tau_{\nu}$. The number of times each $\tau_{v}$ appears in the reduction is given by $\mathrm{a}_{v}=\frac{1}{\mathrm{~g}} \sum_{\mathrm{i}}\left[\chi_{\tau_{v}}\left(\mathrm{~h}_{\mathrm{i}} \mid \mathbf{v}_{\mathrm{i}}\right)\right]^{*} \chi_{\Gamma_{\mathrm{k}}}\left(\mathrm{h}_{\mathrm{i}} \mid \mathbf{v}_{\mathrm{i}}\right)$, which leads to the following reduction:

$$
\Gamma_{\mathrm{k}}=2 \tau_{1}+4 \tau_{2}+4 \tau_{3}+2 \tau_{4}
$$

We get all the new coordinates by applying the projection operator $\mathrm{P}^{v}=\sum_{\mathrm{i}}\left[\tau_{v}\left(\mathrm{~h}_{\mathrm{i}} \mid \mathbf{v}_{\mathrm{i}}\right)\right]^{*}\left(\mathrm{~h}_{\mathrm{i}} \mid \mathbf{v}_{\mathrm{i}}\right)$ to all the Fourier components $\mathrm{s}_{1 \mathrm{x}}^{\mathrm{k}}, \mathrm{s}_{1 \mathrm{y}}^{\mathrm{k}}, \mathrm{s}_{1 \mathrm{z}}^{\mathrm{k}}, \mathrm{s}_{2 \mathrm{x}}^{\mathrm{k}} \ldots \ldots \mathrm{s}_{4 \mathrm{z}}^{\mathrm{k}}$ and we obtain their components:

For representation $\tau_{1}$

$$
\begin{aligned}
& \mathrm{S}_{1}^{1}=\mathrm{s}_{1 \mathrm{y}}^{\mathrm{k}}-\mathrm{a} \mathrm{s}_{2 \mathrm{y}}^{\mathrm{k}} \\
& \mathrm{S}_{1}^{2}=\mathrm{s}_{3 \mathrm{y}}^{\mathrm{k}}-\mathrm{a} \mathrm{s}_{4 \mathrm{y}}^{\mathrm{k}}
\end{aligned}
$$

For representation $\tau_{2}$

$$
\begin{aligned}
& S_{2}^{1}=s_{1 x}^{k}-a s_{2 x}^{k} \\
& S_{2}^{2}=s_{1 z}^{k}+a s_{2 z}^{k} \\
& S_{2}^{3}=s_{3 x}^{k}-a s_{4 x}^{k} \\
& S_{2}^{4}=s_{3 z}^{k}+a s_{4 z}^{k}
\end{aligned}
$$

For representation $\tau_{3}$

$$
\begin{aligned}
& S_{3}^{1}=s_{1 x}^{k}+a s_{2 x}^{k} \\
& S_{3}^{2}=s_{1 z}^{k}-a_{2 z}^{k} \\
& S_{3}^{3}=s_{3 x}^{k}+a s_{4 x}^{k} \\
& S_{3}^{4}=s_{3 z}^{k}-a_{4 z}^{k}
\end{aligned}
$$

For representation $\tau_{4}$

$$
\begin{aligned}
& \mathrm{S}_{4}^{1}=\mathrm{s}_{1 \mathrm{y}}^{\mathrm{k}}+\mathrm{as}_{2 \mathrm{y}}^{\mathrm{k}} \\
& \mathrm{S}_{4}^{2}=\mathrm{s}_{3 \mathrm{y}}^{\mathrm{k}}+\mathrm{as}_{4 \mathrm{y}}^{\mathrm{k}}
\end{aligned}
$$

If the magnetic structure corresponds to representation $\tau_{\nu}$ one writes down that the coordinates of the vectors corresponding to all the other representations are zero. This provides the following relations between the coordinates:

For representation $\tau_{1}$

$$
\begin{array}{lll}
s_{1 x}^{k}=s_{2 x}^{k}=0 & & s_{3 x}^{k}=s_{4 x}^{k}=0 \\
s_{1 y}^{k}=-\operatorname{ss}_{2 y}^{k} & \text { and } & s_{3 y}^{k}=-a s_{4 y}^{k} \\
s_{1 z}^{k}=s_{2 z}^{k}=0 & & s_{3 z}^{k}=s_{4 z}^{k}=0
\end{array}
$$


which corresponds to magnetic moments aligned along Oy with a phase relation between the moments of atoms $\operatorname{Pr}_{1}$ and $\operatorname{Pr}_{2}$ as well as between atoms $\operatorname{Pr}_{3}$ and $\operatorname{Pr}_{4}$.

$$
\mathrm{s}_{2 \mathrm{y}}^{\mathrm{k}}=-\mathrm{s}_{1 \mathrm{y}}^{\mathrm{k}} \mathrm{e}^{-\mathrm{i} \pi \mathrm{k}_{\mathrm{z}}} \quad \text { and } \quad \mathrm{s}_{4 \mathrm{y}}^{\mathrm{k}}=-\mathrm{s}_{3 \mathrm{y}}^{\mathrm{k}} \mathrm{e}^{-\mathrm{i} \pi \mathrm{k}_{\mathrm{z}}}
$$

The structure found this way provides no phase relation between the components of atoms $\operatorname{Pr}_{1}$ and $\operatorname{Pr}_{2}$ on the one hand and atoms $\operatorname{Pr}_{3}$ and $\operatorname{Pr}_{4}$ on the other hand. There are 3 parameters to be determined experimentally: 2 lengths and one phase.

With the same procedure, one gets for representation $\tau_{2}$

$$
\begin{array}{lll}
\mathrm{s}_{2 \mathrm{x}}^{\mathrm{k}}=-\mathrm{s}_{1 \mathrm{x}}^{\mathrm{k}} \mathrm{e}^{-\mathrm{i} \pi \mathrm{k}_{\mathrm{z}}} & \mathrm{s}_{4 \mathrm{x}}^{\mathrm{k}}=-\mathrm{s}_{3 \mathrm{x}}^{\mathrm{k}} \mathrm{e}^{-\mathrm{i} \pi \mathrm{k}_{\mathrm{z}}} \\
\mathrm{s}_{2 \mathrm{z}}^{\mathrm{k}}=\mathrm{s}_{1 \mathrm{z}}^{\mathrm{k}} \mathrm{e}^{-\mathrm{i} \pi \mathrm{k}_{\mathrm{z}}} & \text { and } & \mathrm{s}_{4 \mathrm{z}}^{\mathrm{k}}=\mathrm{s}_{3 \mathrm{z}}^{\mathrm{k}} \mathrm{e}^{-\mathrm{i} \pi \mathrm{k}_{\mathrm{z}}}
\end{array}
$$

In this case there are 7 parameters to be determined experimentally: 4 lengths and 3 phases.

For representation $\tau_{3}$

$$
\begin{aligned}
& \mathrm{s}_{2 \mathrm{x}}^{\mathrm{k}}=\mathrm{s}_{1 \mathrm{x}}^{\mathrm{k}} \mathrm{e}^{-\mathrm{i} \pi \mathrm{k}_{\mathrm{z}}} \\
& \mathrm{s}_{2 \mathrm{z}}^{\mathrm{k}}=-\mathrm{s}_{1 \mathrm{z}}^{\mathrm{k}} \mathrm{e}^{-\mathrm{i} \pi \mathrm{k}_{\mathrm{z}}}
\end{aligned} \quad \text { and } \quad \begin{aligned}
& \mathrm{s}_{4 \mathrm{x}}^{\mathrm{k}}=\mathrm{s}_{3 \mathrm{x}}^{\mathrm{k}} \mathrm{e}^{-\mathrm{i} \pi \mathrm{k}_{\mathrm{z}}} \\
& \mathrm{s}_{4 \mathrm{z}}^{\mathrm{k}}=-\mathrm{s}_{3 \mathrm{z}}^{\mathrm{k}} \mathrm{e}^{-\mathrm{i} \pi \mathrm{k}_{\mathrm{z}}}
\end{aligned}
$$

For representation $\tau_{4}$

$$
\mathrm{s}_{2 \mathrm{y}}^{\mathrm{k}}=\mathrm{s}_{1 \mathrm{y}}^{\mathrm{k}} \mathrm{e}^{-\mathrm{i} \pi \mathrm{k}_{\mathrm{z}}} \quad \text { and } \quad \mathrm{s}_{4 \mathrm{y}}^{\mathrm{k}}=\mathrm{s}_{3 \mathrm{y}}^{\mathrm{k}} \mathrm{e}^{-\mathrm{i} \pi \mathrm{k}_{\mathrm{z}}}
$$

For all the irreducible representations, there is no relation between the group of atoms $\operatorname{Pr}_{1}, \operatorname{Pr}_{2}$ and atoms $\operatorname{Pr}_{3}, \operatorname{Pr}_{4}$. They are not connected in the small group $\mathrm{G}_{\mathrm{k}}$. This relation will be restored if one takes advantage of the conjugation operator and the co-representations.

\section{VI.2 Co-representation analysis}

\section{VI.2.1 The magnetic little group $M_{k}$}

We shall now introduce the conjugation operator $\mathrm{C}$ in the representation analysis. The magnetic little group is black and white: $\mathrm{M}_{\mathrm{k}}=\mathrm{G}_{\mathrm{k}}+\mathrm{Ch}_{25} \mathrm{G}_{\mathrm{k}}$ with the reversing element $\mathrm{a}_{0}=\mathrm{Ch}_{25}$ where $\mathrm{h}_{25}$ is the inversion operator $(-\mathrm{x},-\mathrm{y},-\mathrm{z})$. This group has now 8 elements: $\mathrm{h}_{1}, \mathrm{~h}_{4}, \mathrm{~h}_{26}, \mathrm{~h}_{27}, \mathrm{Ch}_{25}, \mathrm{Ch}_{25} \mathrm{~h}_{4}=\mathrm{Ch}_{28}$, $\mathrm{Ch}_{25} \mathrm{~h}_{26}=\mathrm{Ch}_{2}$ and $\mathrm{Ch}_{25} \mathrm{~h}_{27}=\mathrm{Ch}_{3}$.

We first write down the action of all the operators on the permutation of the Pr atoms.

\begin{tabular}{|l|l|l|l|l|l|l|l|}
\hline $\begin{array}{c}\mathrm{h}_{1} \\
(\mathrm{x}, \mathrm{y}, \mathrm{z})\end{array}$ & \multicolumn{1}{|c|}{$\begin{array}{c}\mathrm{h}_{4} \\
(-\mathrm{x}+1 / 2,-\mathrm{y}, \mathrm{z}+1 / 2)\end{array}$} & $\begin{array}{c}\mathrm{h}_{26} \\
(-\mathrm{x}+1 / 2, \mathrm{y}+1 / 2, \mathrm{z}+1 / 2)\end{array}$ & $\begin{array}{c}\mathrm{h}_{27} \\
(\mathrm{x}, \mathrm{y}+1 / 2, \mathrm{z})\end{array}$ & $\begin{array}{c}\mathrm{Ch}_{25} \\
(-\mathrm{x}, \mathrm{y}, \mathrm{z})\end{array}$ & $\begin{array}{c}\mathrm{Ch}_{28} \\
(\mathrm{x}-1 / 2, \mathrm{y}, \mathrm{z}-1 / 2)\end{array}$ & $\begin{array}{c}\mathrm{Ch}_{2} \\
(\mathrm{x}-1 / 2,-\mathrm{y}-1 / 2,-\mathrm{z}-1 / 2)\end{array}$ & $\begin{array}{c}\mathrm{Ch}_{3} \\
(-\mathrm{x}, \mathrm{y}-1 / 2, \mathrm{z})\end{array}$ \\
\hline $\mathrm{Pr}_{1}$ & $\mathrm{Pr}_{2}+[0,-1,0]$ & $\operatorname{Pr}_{2}$ & $\operatorname{Pr}_{1}$ & $\operatorname{Pr}_{3}+[0,-1,0]$ & $\operatorname{Pr}_{4}+[-1,0,-1]$ & $\operatorname{Pr}_{4}+[-1,-1,-1]$ & $\operatorname{Pr}_{3}+[0,-1,0]$ \\
\hline $\mathrm{Pr}_{2}$ & $\operatorname{Pr}_{1}+[0,-1,1]$ & $\operatorname{Pr}_{1}+[0,1,1]$ & $\operatorname{Pr}_{2}+[0,-1,0]$ & $\operatorname{Pr}_{4}+[-1,-1,-1]$ & $\operatorname{Pr}_{3}+[0,0,-1]$ & $\operatorname{Pr}_{3}+[0,-2,-1]$ & $\operatorname{Pr}_{4}+[-1,0,-1]$ \\
\hline $\mathrm{Pr}_{3}$ & $\mathrm{Pr}_{4}+[0,-1,0]$ & $\operatorname{Pr}_{4}+[0,1,0]$ & $\operatorname{Pr}_{3}+[0,-1,0]$ & $\operatorname{Pr}_{1}+[0,-1,0]$ & $\operatorname{Pr}_{2}+[-1,0,-1]$ & $\operatorname{Pr}_{2}+[-1,-2,-1]$ & $\operatorname{Pr}_{1}$ \\
\hline $\mathrm{Pr}_{4}$ & $\operatorname{Pr}_{3}+[0,-1,1]$ & $\operatorname{Pr}_{3}+[0,0,1]$ & $\operatorname{Pr}_{4}$ & $\operatorname{Pr}_{2}+[-1,-1,-1]$ & $\operatorname{Pr}_{1}+[0,0,-1]$ & $\operatorname{Pr}_{1}+[0,-1,-1]$ & $\operatorname{Pr}_{2}+[-1,-1,-1]$ \\
\hline
\end{tabular}

\section{VI.2.2 The natural co-representation}

Then we want to figure out the natural co-representation $\mathrm{c} \Gamma_{\mathrm{k}}$ which expresses the action of all the operators of the group $\mathrm{M}_{\mathrm{k}}$ on the magnetic components $\mathrm{s}_{\mathrm{j} \alpha}^{\mathrm{k}}$ and $\mathrm{s}_{\mathrm{j} \alpha}^{* \mathrm{k}}$. To do that, we must remember these two points:

1) An operator $h_{i}$ transforms a component $s_{j \alpha}^{k}$ in another component (or a linear combination of components) $\mathrm{s}_{\mathrm{j} \alpha}^{\mathrm{k}}$ and a component $\mathrm{s}_{\mathrm{j} \alpha}^{* \mathrm{k}}$ in another component $\mathrm{s}_{\mathrm{j} \alpha}^{* \mathrm{k}}$, while an operator $\mathrm{Ch}_{i}$ transforms a component $s_{j \alpha}^{k}$ in a component (or a linear combination of components) of type $s_{j \alpha}^{* k}$ and a component $s_{j \alpha}^{* k}$ in a component of type $s_{j \alpha}^{k}$. 


\section{Contribution of Symmetries in Condensed Matter}

2) When a rotation (or a rotation-inversion) sends an atom in a next cell, we have to keep in mind that we are here in the co-group of the vector $\mathrm{k}$ and the translation part of the co-representation is $\mathbf{e}^{-\mathbf{i k T}}$ for a translation which applies as well on a component $\mathrm{s}_{\mathrm{j} \alpha}^{\mathrm{k}}$ as on a component $\mathrm{s}_{\mathrm{j} \alpha}^{* \mathrm{k}}$.

The action of all the operators of the small group $\mathrm{M}_{\mathrm{k}}=\mathrm{G}_{\mathrm{k}}+\mathrm{Ch}_{25} \mathrm{G}_{\mathrm{k}}$ is given in the next table:

\begin{tabular}{|c|c|c|c|c|c|c|c|c|}
\hline component & $\underset{(\mathrm{x}, \mathrm{y}, \mathrm{z})}{\mathrm{h}_{1}}$ & $\begin{array}{c}\mathrm{h}_{4} \\
(-\mathrm{x}+1 / 2,-\mathrm{y}, \mathrm{z}+1 / 2) \\
\end{array}$ & $\begin{array}{c}\mathrm{h}_{26} \\
(-\mathrm{x}+1 / 2, \mathrm{y}+1 / 2, \mathrm{z}+1 / 2)\end{array}$ & $\begin{array}{c}\mathrm{h}_{27} \\
(\mathrm{x}, \mathrm{y}+1 / 2, \mathrm{z}) \\
.\end{array}$ & $\begin{array}{c}\mathrm{Ch}_{25} \\
(-\mathrm{x},-\mathrm{y},-\mathrm{z})\end{array}$ & $\begin{array}{c}\mathrm{Ch}_{28} \\
(\mathrm{x}-1 / 2, \mathrm{y}, \mathrm{z}-\mathrm{-}-1 / 2) \\
\end{array}$ & $\underset{(\mathrm{x}-1 / 2,-\mathrm{y}-1 / 2,-\mathrm{z}-1 / 2)}{\mathrm{Ch}_{2}}$ & $\underset{(-x, y-1 / 2,-z)}{\mathrm{Ch}_{3}}$ \\
\hline $\mathrm{s}_{1 \mathrm{x}}^{\mathrm{k}}$ & $\mathrm{s}_{1 \mathrm{x}}^{\mathrm{k}}$ & $-\mathrm{s}_{2 \mathrm{x}}^{\mathrm{k}}$ & $\mathrm{s}_{2 \mathrm{x}}^{\mathrm{k}}$ & $-\mathrm{s}_{1 \mathrm{x}}^{\mathrm{k}}$ & $\mathrm{s}_{3 \mathrm{x}}^{* \mathrm{k}}$ & $-\mathrm{s}_{4 \mathrm{x}}^{* \mathrm{k}} \mathrm{a}^{2}$ & $\mathrm{~s}_{4 \mathrm{x}}^{* \mathrm{k}} \mathrm{a}^{2}$ & $-\mathrm{S}_{3 \mathrm{x}}^{* \mathrm{k}}$ \\
\hline $\mathrm{s}_{1 \mathrm{y}}^{\mathrm{k}}$ & $\mathrm{s}_{1 \mathrm{y}}^{\mathrm{k}}$ & $-s_{2 y}^{2 k}$ & $-s_{2 y}^{k x}$ & $\mathrm{~s}_{1 \mathrm{y}}^{\mathrm{k}}$ & $\mathrm{s}_{3 \mathrm{y}}^{* \mathrm{k}_{\mathrm{k}}}$ & $-\mathrm{s}_{4 \mathrm{y}}^{* \mathrm{k}} \mathrm{a}^{2}$ & $-\mathrm{s}_{4 \mathrm{y}}^{* \mathrm{*}} \mathrm{a}^{2}$ & $\mathrm{~s}_{3 \mathrm{y}}^{* \mathrm{k}_{\mathrm{k}}}$ \\
\hline $\mathrm{s}_{1 \mathrm{z}}^{\mathrm{k}}$ & $s_{1 z}^{k}$ & $\mathrm{~s}_{2 \mathrm{z}}^{\mathrm{k}}$ & $-\mathrm{s}_{2 \mathrm{z}}^{\mathrm{k}}$ & $-\mathrm{s}_{1 \mathrm{z}}^{\mathrm{k}}$ & $\mathrm{s}_{3 \mathrm{z}}^{* \mathrm{k}}$ & $\mathrm{s}_{4 \mathrm{z}}^{* \mathrm{k}} \mathrm{a}^{2}$ & $-\mathrm{s}_{4 \mathrm{z}}^{* \mathrm{k}} \mathrm{a}^{2}$ & $-\mathrm{s}_{3 \mathrm{z}}^{* \mathrm{k}_{\mathrm{k}}}$ \\
\hline $\mathrm{s}_{2 \mathrm{x}}^{\mathrm{k}}$ & $\mathrm{s}_{2 \mathrm{x}}^{\mathrm{k}}$ & $-\mathrm{s}_{1 x}^{\mathrm{k}} \mathrm{a}^{-2}$ & $\mathrm{~s}_{1 \mathrm{x}}^{\mathrm{k}} \mathrm{a}^{-2}$ & $-\mathrm{s}_{2 \mathrm{x}}^{\mathrm{k}}$ & $\mathrm{s}_{4 \mathrm{x}}^{* \mathrm{k}} \mathrm{a}^{2}$ & $-\mathrm{s}_{3 \mathrm{x}}^{* \mathrm{k}} \mathrm{a}^{2}$ & $\mathrm{~s}_{3 \mathrm{x}}^{* \mathrm{k}} \mathrm{a}^{2}$ & $-\mathrm{s}_{4 \mathrm{x}}^{* \mathrm{k}} \mathrm{a}^{2}$ \\
\hline $\mathrm{s}_{2 \mathrm{y}}^{\mathrm{k}}$ & $s_{2 y}^{k}$ & $-s_{1 y}^{k} a^{-2}$ & $-s_{1 y}^{k} a^{-2}$ & $\mathrm{~s}_{2 \mathrm{y}}^{\mathrm{k}}$ & $s_{4 y}^{* k} a^{2}$ & $-\mathrm{s}_{3 \mathrm{y}}^{* \mathrm{k}} \mathrm{a}^{2}$ & $-\mathrm{s}_{3 \mathrm{y}}^{* \mathrm{*k}} \mathrm{a}^{2}$ & $\mathrm{~s}_{4 \mathrm{y}}^{* \mathrm{k}} \mathrm{a}^{2}$ \\
\hline $\mathrm{s}_{2 \mathrm{z}}^{\mathrm{k}}$ & $s_{2 z}^{k}$ & $\mathrm{~s}_{1 \mathrm{z}}^{\mathrm{k}} \mathrm{a}^{-2}$ & $-s_{1 z}^{k} a^{-2}$ & $-\mathrm{s}_{2 \mathrm{z}}^{\mathrm{k}}$ & $\mathrm{s}_{4 \mathrm{z}}^{* \mathrm{k}} \mathrm{a}^{2}$ & $\mathrm{~s}_{3 \mathrm{z}}^{* \mathrm{k}} \mathrm{a}^{2}$ & $-\mathrm{s}_{3 \mathrm{z}}^{* \mathrm{k}} \mathrm{a}^{2}$ & $-\mathrm{s}_{4 \mathrm{z}}^{* \mathrm{k}} \mathrm{a}^{2}$ \\
\hline $\mathrm{s}_{3 \mathrm{x}}^{\mathrm{k}}$ & $\mathrm{s}_{3 \mathrm{x}}^{\mathrm{k}}$ & $-\mathrm{s}_{4 \mathrm{x}}^{\mathrm{k}}$ & $\mathrm{s}_{4 \mathrm{x}}^{\mathrm{k}}$ & $-\mathrm{s}_{3 \mathrm{x}}^{\mathrm{k}}$ & $\mathrm{s}_{1 \mathrm{x}}^{* \mathrm{k}}$ & $-\mathrm{s}_{2 \mathrm{x}}^{* \mathrm{k}} \mathrm{a}^{2}$ & $\mathrm{~s}_{2 \mathrm{x}}^{* \mathrm{k}_{\mathrm{k}}} \mathrm{a}^{2}$ & $-\mathrm{s}_{1 \mathrm{x}}^{* \mathrm{k}}$ \\
\hline$s_{3 y}^{k}$ & $\mathrm{~s}_{3 \mathrm{y}}^{\mathrm{k}}$ & $-\mathrm{s}_{4 \mathrm{y}}^{\mathrm{k}}$ & $-s_{4 y}^{k}$ & $\mathrm{~s}_{3 \mathrm{y}}^{\mathrm{k}}$ & $\mathrm{s}_{1 \mathrm{y}}^{* \mathrm{k}}$ & $-\mathrm{s}_{2 \mathrm{y}}^{* \mathrm{k}} \mathrm{a}^{2}$ & $-\mathrm{s}_{2 \mathrm{y}}^{* \mathrm{k}} \mathrm{a}^{2}$ & $\mathrm{~s}_{1 \mathrm{y}}^{* \mathrm{k}}$ \\
\hline $\mathrm{s}_{3 \mathrm{z}}^{\mathrm{k}}$ & $\mathrm{s}_{3 \mathrm{z}}^{\mathrm{k}}$ & $\mathrm{s}_{4 \mathrm{z}}^{\mathrm{k}}$ & $-\mathrm{s}_{4 \mathrm{z}}^{\mathrm{k}}$ & $-\mathrm{s}_{3 \mathrm{z}}^{\mathrm{k}}$ & $\mathrm{s}_{1 \mathrm{z}}^{* \mathrm{k}}$ & $\mathrm{s}_{2 \mathrm{z}}^{* \mathrm{k}} \mathrm{a}^{2}$ & $-\mathrm{s}_{2 \mathrm{z}}^{* \mathrm{k}} \mathrm{a}^{2}$ & $-\mathrm{s}_{1 \mathrm{z}}^{* \mathrm{k}}$ \\
\hline $\mathrm{s}_{4 \mathrm{x}}^{\mathrm{k}}$ & $\mathrm{s}_{4 \mathrm{x}}^{\mathrm{k}}$ & $-s_{3 x}^{k} a^{-2}$ & $s_{3 x}^{k} a^{-2}$ & $-s_{4 x}^{k}$ & $s_{2 x}^{* k} a^{2}$ & $-\mathrm{s}_{1 \mathrm{x}}^{* \mathrm{k}} \mathrm{a}^{2}$ & $\mathrm{~s}_{1 \mathrm{x}}^{* \mathrm{k}} \mathrm{a}^{2}$ & $-s_{2 x}^{* k} a^{2}$ \\
\hline $\mathrm{s}_{4 \mathrm{y}}^{\mathrm{k}}$ & $\mathrm{s}_{4 \mathrm{y}}^{\mathrm{k}}$ & $-s_{3 y}^{k} a^{-2}$ & $-s_{3 y}^{k} a^{-2}$ & $\mathrm{~s}_{4 \mathrm{y}}^{\mathrm{k}}$ & $s_{2 y}^{* k} a^{2}$ & $-\mathrm{s}_{1 \mathrm{y}}^{* \mathrm{k}} \mathrm{a}^{2}$ & $-\mathrm{s}_{1 \mathrm{y}}^{* \mathrm{*}_{\mathrm{k}}} \mathrm{a}^{2}$ & $s_{2 y}^{* k} a^{2}$ \\
\hline $\mathrm{s}_{4 \mathrm{z}}^{\mathrm{k}}$ & $\mathrm{s}_{4 \mathrm{z}}^{\mathrm{k}}$ & $s_{3 z}^{k} a^{-2}$ & $-s_{3 z}^{k} a^{-2}$ & $-\mathrm{s}_{4 \mathrm{z}}^{\mathrm{k}}$ & $\mathrm{s}_{2 \mathrm{z}}^{* \mathrm{k}} \mathrm{a}^{2}$ & $\mathrm{~s}_{1 \mathrm{z}}^{* \mathrm{k}} \mathrm{a}^{2}$ & $-\mathrm{s}_{1 \mathrm{z}}^{* \mathrm{k}} \mathrm{a}^{2}$ & $-\mathrm{s}_{2 \mathrm{z}}^{* \mathrm{k}} \mathrm{a}^{2}$ \\
\hline $\mathrm{s}_{1 \mathrm{x}}^{* \mathrm{k}}$ & $\mathrm{s}_{1 \mathrm{x}}^{* \mathrm{k}}$ & $-\mathrm{s}_{2 \mathrm{x}}^{* \mathrm{k}}$ & $\mathrm{s}_{2 \mathrm{x}}^{* \mathrm{k}}$ & $-\mathrm{s}_{1 \mathrm{x}}^{* \mathrm{*k}}$ & $\mathrm{s}_{3 \mathrm{x}}^{\mathrm{k}}$ & $-\mathrm{s}_{4 \mathrm{x}}^{\mathrm{k}} \mathrm{a}^{2}$ & $\mathrm{~s}_{4 \mathrm{x}}^{\mathrm{k}} \mathrm{a}^{2}$ & $-\mathrm{s}_{3 \mathrm{x}}^{\mathrm{k}}$ \\
\hline $\mathrm{s}_{1 \mathrm{y}}^{* \mathrm{k}}$ & $\mathrm{s}_{1 \mathrm{y}}^{* \mathrm{k}}$ & $-\mathrm{s}_{2 \mathrm{y}}^{* \mathrm{*}_{\mathrm{k}}}$ & $-s_{2 y}^{* k k}$ & $\mathrm{~s}_{1 \mathrm{y}}^{* \mathrm{k}}$ & $\mathrm{s}_{3 \mathrm{y}}^{\mathrm{k}}$ & $-\mathrm{s}_{4 \mathrm{y}}^{\mathrm{kx}} \mathrm{a}^{2}$ & $-\mathrm{s}_{4 \mathrm{y}}^{\mathrm{k}} \mathrm{a}^{2}$ & $\mathrm{~s}_{3 \mathrm{y}}^{\mathrm{k}}$ \\
\hline $\mathrm{s}_{1 \mathrm{z}}^{* \mathrm{k}}$ & $\mathrm{s}_{1 \mathrm{z}}^{* \mathrm{k}}$ & $\mathrm{s}_{2 \mathrm{z}}^{* \mathrm{k}}$ & $-\mathrm{s}_{2 \mathrm{z}}^{* \mathrm{k}}$ & $-\mathrm{s}_{1 \mathrm{z}}^{* \mathrm{k}}$ & $\mathrm{s}_{3 \mathrm{z}}^{\mathrm{k}}$ & $\mathrm{s}_{4 \mathrm{z}}^{\mathrm{k}} \mathrm{a}^{2}$ & $-\mathrm{s}_{4 \mathrm{z}}^{\mathrm{k}} \mathrm{a}^{2}$ & $-s_{3 z}^{k}$ \\
\hline $\mathrm{s}_{2 \mathrm{x}}^{* \mathrm{k}}$ & $\mathrm{s}_{2 \mathrm{x}}^{*{ }^{*} \mathrm{k}}$ & $-s_{1 x}^{* k} a^{-2}$ & $s_{1 x}^{* k} a^{-2}$ & $-\mathrm{s}_{2 \mathrm{x}}^{*{ }_{\mathrm{*}} \mathrm{k}}$ & $s_{4 x}^{k} a^{2}$ & $-s_{3 x}^{k} a^{2}$ & $\mathrm{~s}_{3 \mathrm{x}}^{\mathrm{k}} \mathrm{a}^{2}$ & $-\mathrm{s}_{4 \mathrm{x}}^{\mathrm{k}} \mathrm{a}^{2}$ \\
\hline $\mathrm{s}_{2 \mathrm{k}}^{* \mathrm{k}}$ & $\mathrm{s}_{2 \mathrm{y}}^{* \mathrm{k}_{\mathrm{k}}}$ & $-\mathrm{s}_{1 \mathrm{y}}^{* \mathrm{*k}} \mathrm{a}^{-2}$ & $-\mathrm{s}_{1 \mathrm{y}}^{* \mathrm{*k}} \mathrm{a}^{-2}$ & $\mathrm{~s}_{2 \mathrm{y}}^{*{ }^{*} \mathrm{k}}$ & $\mathrm{s}_{4 \mathrm{y}}^{\mathrm{k}} \mathrm{a}^{2}$ & $-\mathrm{s}_{3 \mathrm{y}}^{\mathrm{k}} \mathrm{a}^{2}$ & $-s_{3 y}^{k} a^{2}$ & $\mathrm{~s}_{4 y}^{\mathrm{k}} \mathrm{a}^{2}$ \\
\hline $\mathrm{s}_{2 \mathrm{z}}^{* \mathrm{k}}$ & $\mathrm{s}_{2 \mathrm{z}}^{* \mathrm{k}}$ & $\mathrm{s}_{1 \mathrm{z}}^{* \mathrm{k}} \mathrm{a}^{-2}$ & $-s_{1 z}^{* k} a^{-2}$ & $-\mathrm{s}_{2 \mathrm{z}}^{*{ }^{*} \mathrm{k}}$ & $\mathrm{s}_{4 \mathrm{z}}^{\mathrm{k}} \mathrm{a}^{2}$ & $\mathrm{~s}_{3 \mathrm{z}}^{\mathrm{k}} \mathrm{a}^{2}$ & $-\mathrm{s}_{3 \mathrm{z}}^{\mathrm{k}} \mathrm{a}^{2}$ & $-s_{4 z}^{k} a^{2}$ \\
\hline $\mathrm{s}_{3 \mathrm{x}}^{* \mathrm{w}_{\mathrm{k}}}$ & $\mathrm{s}_{3 \mathrm{x}}^{* \mathrm{k}_{\mathrm{k}}}$ & $-\mathrm{s}_{4 \mathrm{x}}^{* \mathrm{k}}$ & $\mathrm{s}_{4 \mathrm{x}}^{* \mathrm{~F}_{\mathrm{k}}}$ & $-\mathrm{s}_{3 \mathrm{x}}^{* *_{\mathrm{k}}}$ & $\mathrm{s}_{1 \mathrm{x}}^{\mathrm{k}}$ & $-\mathrm{s}_{2 \mathrm{x}}^{\mathrm{k}} \mathrm{a}^{2}$ & $\mathrm{~s}_{2 \mathrm{x}}^{\mathrm{k}} \mathrm{a}^{2}$ & $-\mathrm{s}_{1 \mathrm{x}}^{\mathrm{k}}$ \\
\hline $\mathrm{s}_{3 \mathrm{y}}^{*{ }^{* \mathrm{k}}}$ & $\mathrm{s}_{3 \mathrm{y}}^{*{ }_{\mathrm{k}}^{\mathrm{k}}}$ & $-\mathrm{s}_{4 \mathrm{y}}^{* \mathrm{k}}$ & $-\mathrm{s}_{4 \mathrm{y}}^{* \mathrm{k}}$ & $\mathrm{s}_{3 \mathrm{y}}^{*{ }^{*} \mathrm{k}}$ & $\mathrm{s}_{1 \mathrm{y}}^{\mathrm{k}}$ & $-\mathrm{s}_{2 \mathrm{y}}^{\mathrm{k}} \mathrm{a}^{2}$ & $-s_{2 y}^{k} a^{2}$ & $\mathrm{~s}_{1 \mathrm{y}}^{\mathrm{k}}$ \\
\hline $\mathrm{s}_{3 \mathrm{z}}^{*{ }^{*} \mathrm{k}}$ & $\mathrm{s}_{3 z}^{* \mathrm{k}}$ & $\mathrm{s}_{4 \mathrm{z}}^{* \mathrm{k}}$ & $-\mathrm{s}_{4 \mathrm{z}}^{*{ }^{*} \mathrm{k}}$ & $-\mathrm{s}_{3 z}^{* \mathrm{k}}$ & $\mathrm{s}_{1 \mathrm{z}}^{\mathrm{k}}$ & $\mathrm{s}_{2 \mathrm{z}}^{\mathrm{k}} \mathrm{a}^{2}$ & $-\mathrm{s}_{2 \mathrm{z}}^{\mathrm{k}} \mathrm{a}^{2}$ & $-\mathrm{s}_{1 \mathrm{z}}^{\mathrm{k}}$ \\
\hline $\mathrm{s}_{4 \mathrm{x}}^{* \mathrm{k} k}$ & $\mathrm{~s}_{4 \mathrm{x}}^{* \mathrm{k}}$ & $-\mathrm{s}_{3 \mathrm{x}}^{* \mathrm{k}} \mathrm{a}^{-2}$ & $s_{3 x}^{* k} a^{-2}$ & $-\mathrm{s}_{4 \mathrm{x}}^{* \mathrm{*}_{\mathrm{k}}}$ & $s_{2 x}^{k} a^{2}$ & $-\mathrm{s}_{1 \mathrm{x}}^{\mathrm{k}} \mathrm{a}^{2}$ & $\mathrm{~s}_{1 \mathrm{x}}^{\mathrm{k}} \mathrm{a}^{2}$ & $-s_{2 x}^{k} a^{2}$ \\
\hline $\mathrm{s}_{4 y}^{* k \mathrm{k}}$ & $\mathrm{s}_{4 \mathrm{y}}^{* \mathrm{k}}$ & $-s_{3 y}^{* k} a^{*-2}$ & $-s_{3 y}^{* k} a^{-2}$ & $\mathrm{~s}_{4 y}^{* k_{k}}$ & $s_{2 y}^{k x} a^{2}$ & $-s_{1 y}^{k} a^{2}$ & $-\mathrm{s}_{1 \mathrm{y}}^{\mathrm{k}} \mathrm{a}^{2}$ & $\mathrm{~s}_{2 \mathrm{y}}^{\mathrm{k}} \mathrm{a}^{2}$ \\
\hline $\mathrm{s}_{4 \mathrm{z}}^{* \mathrm{k}}$ & $\mathrm{s}_{4 \mathrm{z}}^{* \mathrm{k}}$ & $\mathrm{s}_{3 \mathrm{z}}^{* \mathrm{k}} \mathrm{a}^{-2}$ & $-\mathrm{s}_{3 \mathrm{z}}^{* \mathrm{k}} \mathrm{a}^{-2}$ & $-\mathrm{s}_{4 \mathrm{z}}^{* \mathrm{k}}$ & $s_{2 z}^{k} a^{2}$ & $\mathrm{~s}_{1 \mathrm{z}}^{\mathrm{k}} \mathrm{a}^{2}$ & $\mathrm{~s}_{1 \mathrm{z}}^{\mathrm{k}} \mathrm{a}^{2}$ & $-\mathrm{s}_{2 \mathrm{z}}^{\mathrm{k}} \mathrm{a}^{2}$ \\
\hline$\chi\left(\mathrm{c} \Gamma_{\mathrm{k}}\right)$ & 24 & 0 & 0 & -8 & 0 & 0 & 0 & 0 \\
\hline
\end{tabular}

\section{VI.2.3 Irreducible co-representations}

To check the dimension of the irreducible co-representations we have two possibilities:

- Either we look in the Kovalev book in which it is stated that in space group Pnma, with $\mathrm{k}=\left(00 \mathrm{k}_{z}\right)$ : each of the 4 one-dimension irreducible representations $\tau_{v}$ will give two one-dimension irreducible co-representation $\mathrm{c} \tau_{v}+$ and $\mathrm{c} \tau_{v}^{-}$and that these corepresentations are equivalent.

- Or we make use of the reality criterion applied to the irreducible representations of the $G_{k}$ group and calculate the value taken by the sum $\sum_{\mathrm{j}} \chi\left(\mathrm{a}_{\mathrm{j}}^{2}\right)$, the $\mathrm{a}_{j}$ operators being all the operators of the $\mathrm{Ch}_{25} \mathrm{G}_{\mathrm{k}}$ group.

As this sum is equal to 4 , the number of operators in the $G_{k}$ group, the order two co-representation built from each irreducible representation of $G_{k}$ by using matrices (11) and (12) is reducible in two irreducible co-representations:

$$
\begin{array}{ll}
\mathrm{c} \tau_{\nu}^{+}\left(\mathrm{h}_{\mathrm{i}}\right)=\tau_{v}\left(\mathrm{~h}_{\mathrm{i}}\right) & \mathrm{c} \tau_{\nu}^{+}\left(\mathrm{a}_{\mathrm{j}}\right)=\tau_{v}\left(\mathrm{a}_{\mathrm{j}}\left(\mathrm{Ch}_{25}\right)^{-1}\right) \\
\mathrm{c} \tau_{v}^{-}\left(\mathrm{h}_{\mathrm{i}}\right)=\tau_{v}\left(\mathrm{~h}_{\mathrm{i}}\right) & \mathrm{c} \tau_{v}^{-}\left(\mathrm{a}_{\mathrm{j}}\right)=-\tau_{v}\left(\mathrm{a}_{\mathrm{j}}\left(\mathrm{Ch}_{25}\right)^{-1}\right)
\end{array}
$$

As $\mathrm{a}_{\mathrm{j}}\left(\mathrm{Ch}_{25}\right)^{-1}$ is a linear operator, $\tau_{v}\left(\mathrm{a}_{\mathrm{j}}\left(\mathrm{Ch}_{25}\right)^{-1}\right)$ is well defined. 


\section{EPJ Web of Conferences}

Theory predicts also that the solutions represented by $\mathrm{c} \tau_{v}^{+}$and $\mathrm{c} \tau_{v}^{-}$are equivalent.

Applying these formulae, we get the following 8 irreducible co-representations:

\begin{tabular}{|l|l|l|l|l|l|l|l|c|}
\hline Ir. co-rep & $\begin{array}{c}\mathrm{h}_{1} \\
(\mathrm{x}, \mathrm{y}, \mathrm{z})\end{array}$ & $\begin{array}{c}\mathrm{h}_{4} \\
(-\mathrm{x}+1 / 2,-\mathrm{y}, \mathrm{z}+1 / 2)\end{array}$ & $\begin{array}{c}\mathrm{h}_{26} \\
(-\mathrm{x}+1 / 2, \mathrm{y}+1 / 2, \mathrm{z}+1 / 2)\end{array}$ & $\begin{array}{c}\mathrm{h}_{27} \\
(\mathrm{x}, \mathrm{y}+1 / 2, \mathrm{z})\end{array}$ & $\begin{array}{c}\mathrm{Ch}_{25} \\
(-\mathrm{x}, \mathrm{-}, \mathrm{z})\end{array}$ & $\begin{array}{c}\mathrm{Ch}_{28} \\
(\mathrm{x}-1 / 2, \mathrm{y}, \mathrm{z}-1 / 2)\end{array}$ & $\begin{array}{c}\mathrm{Ch}_{2} \\
(\mathrm{x}-1 / 2, \mathrm{y}-1 / 2, \mathrm{z}-1 / 2)\end{array}$ & $\begin{array}{c}\mathrm{Ch}_{3} \\
(\mathrm{x}, \mathrm{y}-1 / 2, \mathrm{z})\end{array}$ \\
\hline $\mathrm{c} \tau_{1}^{+}$ & 1 & $\mathrm{a}^{-1}$ & $\mathrm{a}^{-1}$ & 1 & 1 & $\mathrm{a}$ & $\mathrm{a}$ & 1 \\
\hline $\mathrm{c} \tau_{1}^{-}$ & 1 & $\mathrm{a}^{-1}$ & $\mathrm{a}^{-1}$ & 1 & -1 & $-\mathrm{a}$ & $-\mathrm{a}$ & -1 \\
\hline $\mathrm{c} \tau_{2}^{+}$ & 1 & $\mathrm{a}^{-1}$ & $-\mathrm{a}^{-1}$ & -1 & 1 & $\mathrm{a}$ & $-\mathrm{a}$ & -1 \\
\hline $\mathrm{c} \tau_{2}^{-}$ & 1 & $\mathrm{a}^{-1}$ & $-\mathrm{a}^{-1}$ & -1 & -1 & $-\mathrm{a}$ & $\mathrm{a}$ & 1 \\
\hline $\mathrm{c} \tau_{3}^{+}$ & 1 & $-\mathrm{a}^{-1}$ & $\mathrm{a}^{-1}$ & -1 & 1 & $-\mathrm{a}$ & $\mathrm{a}$ & -1 \\
\hline $\mathrm{c} \tau_{3}^{-}$ & 1 & $-\mathrm{a}^{-1}$ & $\mathrm{a}^{-1}$ & -1 & -1 & $\mathrm{a}$ & $-\mathrm{a}$ & 1 \\
\hline $\mathrm{c} \tau_{4}^{+}$ & 1 & $-\mathrm{a}^{-1}$ & $-\mathrm{a}^{-1}$ & 1 & 1 & $-\mathrm{a}$ & $-\mathrm{a}$ & 1 \\
\hline $\mathrm{c} \tau_{4}^{-}$ & 1 & $-\mathrm{a}^{-1}$ & $-\mathrm{a}^{-1}$ & 1 & -1 & $\mathrm{a}$ & $\mathrm{a}$ & -1 \\
\hline
\end{tabular}

\section{VI.2.4 Decomposition of the natural co-representation}

The decomposition of the natural co-representation into the irreducible co-representations becomes:

$$
\mathrm{c} \Gamma_{\mathrm{k}}=2 \mathrm{c} \tau_{1}^{+}+2 \mathrm{c} \tau_{1}^{-}+4 \mathrm{c} \tau_{2}^{+}+4 \mathrm{c} \tau_{2}^{-}+4 \mathrm{c} \tau_{3}^{+}+4 \mathrm{c} \tau_{3}^{-}+2 \mathrm{c} \tau_{4}^{+}+2 \mathrm{c} \tau_{4}^{-}
$$

The new components for each irreducible co-representation are obtained with the projection operators applied in principle to the more general linear combination of components $\mathrm{s}_{\mathrm{j}, \alpha}^{\mathrm{k}}$ and $\mathrm{s}_{\mathrm{j}, \alpha}^{* \mathrm{k}}$ :

$$
\mathrm{P}_{v}^{ \pm}=\sum_{\mathrm{i}}\left(\mathrm{c} \tau_{v}^{ \pm}\left(\mathrm{h}_{\mathrm{i}}\right)\right)^{*} \mathrm{~h}_{\mathrm{i}}+\sum_{\mathrm{j}}\left(\mathrm{c} \tau_{v}^{ \pm}\left(\mathrm{a}_{\mathrm{j}}\right)\right)^{*} \mathrm{a}_{\mathrm{j}}
$$

We get the following components:

For co-representation $\mathrm{c} \tau_{1}^{+}$

$$
\begin{aligned}
& \mathrm{S}_{1^{+}}^{1}=\mathrm{s}_{1 y}^{\mathrm{k}}-\mathrm{as}_{2 y}^{\mathrm{k}}+\mathrm{s}_{3 y}^{* \mathrm{k}}-\mathrm{as}_{4 y}^{* \mathrm{k}} \\
& \mathrm{S}_{1^{+}}^{2}=\mathrm{s}_{1 y}^{* \mathrm{k}}-\mathrm{as}_{2 y}^{* \mathrm{k}}+\mathrm{s}_{3 y}^{\mathrm{k}}-\mathrm{as}_{4 y}^{\mathrm{k}}
\end{aligned}
$$

For co-representation $\mathrm{c} \tau_{1}^{-}$

$$
\begin{aligned}
& \mathrm{S}_{1^{-}}^{1}=\mathrm{s}_{1 y}^{\mathrm{k}}-\mathrm{as}_{2 y}^{\mathrm{k}}-\mathrm{s}_{3 y}^{* \mathrm{k}}+\mathrm{as}_{4 y}^{* \mathrm{k}} \\
& \mathrm{S}_{1^{-}}^{2}=\mathrm{s}_{1 y}^{* \mathrm{k}}-\mathrm{as}_{2 y}^{* \mathrm{k}}-\mathrm{s}_{3 y}^{\mathrm{k}}+\mathrm{as}_{4 y}^{\mathrm{k}}
\end{aligned}
$$

For co-representation $\mathrm{c} \tau_{2}^{+}$

$$
\begin{aligned}
& S_{2^{+}}^{1}=s_{1 x}^{k}-a s_{2 x}^{k}+s_{3 x}^{* k}-a s_{4 x}^{* k} \\
& S_{2^{+}}^{2}=s_{1 z}^{k}+a s_{2 z}^{k}+s_{3 z}^{* k}+a s_{4 z}^{* k} \\
& S_{2^{+}}^{3}=s_{1 x}^{* k}-a s_{2 x}^{* k}+s_{3 x}^{k}-a s_{4 x}^{k} \\
& S_{2^{+}}^{4}=s_{1 z}^{* k}+a s_{2 z}^{* k}+s_{3 z}^{k}+a s_{4 z}^{k}
\end{aligned}
$$

For co-representation $\mathrm{c} \tau_{2}^{-}$

$$
\begin{aligned}
& S_{2^{-}}^{1}=s_{1 x}^{k}-a s_{2 x}^{k}-s_{3 x}^{* k}+a s_{4 x}^{* k} \\
& S_{2^{-}}^{2}=s_{1 z}^{k}+a s_{2 z}^{k}-s_{3 z}^{* k}-a s_{4 z}^{* k} \\
& S_{2^{-}}^{3}=s_{1 x}^{* k}-a s_{2 x}^{* k}-s_{3 x}^{k}+a s_{4 x}^{k} \\
& S_{2^{-}}^{4}=s_{1 z}^{* k}+a s_{2 z}^{* k}-s_{3 z}^{k}-a s_{4 z}^{k}
\end{aligned}
$$




\section{Contribution of Symmetries in Condensed Matter}

For co-representation $\mathrm{c} \tau_{3}^{+}$

$$
\begin{aligned}
& S_{3^{+}}^{1}=s_{1 x}^{k}+a s_{2 x}^{k}+s_{3 x}^{* k}+a s_{4 x}^{* k} \\
& S_{3^{+}}^{2}=s_{1 z}^{k}-a s_{2 z}^{k}+s_{3 z}^{* k}-a s_{4 z}^{* k} \\
& S_{3^{+}}^{3}=s_{1 x}^{* k}+a s_{2 x}^{* k}+s_{3 x}^{k}+a s_{4 x}^{k} \\
& S_{3^{+}}^{4}=s_{1 z}^{* k}-a s_{2 z}^{* k}+s_{3 z}^{k}-a s_{4 z}^{k}
\end{aligned}
$$

For co-representation $\mathrm{c}_{3}^{-}$

$$
\begin{aligned}
& \mathrm{S}_{3^{-}}^{1}=\mathrm{s}_{1 \mathrm{x}}^{\mathrm{k}}+\mathrm{as}_{2 \mathrm{x}}^{\mathrm{k}}-\mathrm{s}_{3 \mathrm{x}}^{* \mathrm{k}}-\mathrm{as}_{4 \mathrm{x}}^{* \mathrm{k}} \\
& \mathrm{S}_{3^{-}}^{2}=\mathrm{s}_{1 \mathrm{z}}^{\mathrm{k}}-\mathrm{as}_{2 \mathrm{z}}^{\mathrm{k}}-\mathrm{s}_{3 \mathrm{z}}^{* \mathrm{k}}+\mathrm{as}_{4 \mathrm{z}}^{* \mathrm{k}} \\
& \mathrm{S}_{3^{-}}^{3}=\mathrm{s}_{1 \mathrm{x}}^{* \mathrm{k}}+\mathrm{as}_{2 \mathrm{x}}^{* \mathrm{k}}-\mathrm{s}_{3 \mathrm{x}}^{\mathrm{k}}-\mathrm{as}_{4 \mathrm{x}}^{\mathrm{k}} \\
& \mathrm{S}_{3^{-}}^{4^{-}}=\mathrm{s}_{1 \mathrm{z}}^{* \mathrm{k}}-\mathrm{as}_{2 \mathrm{z}}^{* \mathrm{k}}-\mathrm{s}_{3 \mathrm{z}}^{\mathrm{k}}+\mathrm{as}_{4 \mathrm{z}}^{\mathrm{k}}
\end{aligned}
$$

For co-representation $\mathrm{c} \tau_{4}^{+}$

$$
\begin{aligned}
& S_{4^{+}}^{1}=s_{1 y}^{k}+a s_{2 y}^{k}+s_{3 y}^{* k}+a s_{4 y}^{* k} \\
& S_{4^{+}}^{2}=s_{1 y}^{* k}+a s_{2 y}^{* k}+s_{3 y}^{k}+a s_{4 y}^{k}
\end{aligned}
$$

For co-representation $\mathrm{c} \tau_{4}^{-}$

$$
\begin{aligned}
& S_{4^{-}}^{1}=s_{1 y}^{k}+a s_{2 y}^{k}-s_{3 y}^{* k}-a s_{4 y}^{* k} \\
& S_{4^{-}}^{2}=s_{1 y}^{* k}+a s_{2 y}^{* k}-s_{3 y}^{k}-a s_{4 y}^{k}
\end{aligned}
$$

The magnetic components deduced from these relations are given as usual by assuming that if the magnetic structure belongs to co-representation $c \tau_{v}^{ \pm}$, the new coordinates corresponding to this co-representation are not zero while those corresponding to all the other co-representations are zero.

This way one obtains the following equalities:

For co-representation $\mathrm{c} \tau_{1}^{+}$:

$$
\mathrm{s}_{1 \mathrm{y}}^{\mathrm{k}}=-\mathrm{as}_{2 \mathrm{y}}^{\mathrm{k}}=\mathrm{s}_{3 \mathrm{y}}^{* \mathrm{k}}=-\mathrm{as}_{4 \mathrm{y}}^{* \mathrm{k}}
$$

and

$$
\mathrm{s}_{1 \mathrm{y}}^{* \mathrm{k}}=-\mathrm{as}_{2 \mathrm{y}}^{* \mathrm{k}}=\mathrm{s}_{3 \mathrm{y}}^{\mathrm{k}}=-\mathrm{as}_{4 \mathrm{y}}^{\mathrm{k}}
$$

Let us make this important remark which will be relevant for all the corepresentations: the second line is not the conjugate of the first line. Actually the conjugate of $s_{1 y}^{k}$ is $\left(s_{1 y}^{k}\right)^{*}=s_{1 y}^{-k}$ and the conjugate of $\mathrm{a}=\mathrm{e}^{\mathrm{i} \pi \mathrm{k}_{\mathrm{z}}}$ is $\mathrm{a}^{-1}=\mathrm{e}^{-\mathrm{i} \pi \mathrm{k}_{\mathrm{z}}}$. The operation which transforms $\mathrm{s}_{\mathrm{j} \alpha}^{\mathrm{k}}$ in $\mathrm{s}_{j \alpha}^{* \mathrm{k}}$ (a conjugation plus a change of $\mathbf{k}$ in $-\mathbf{k}$ ) does not change the representation of the translation and as a consequence transforms $\mathrm{a}=\mathrm{e}^{\mathrm{i} \pi \mathrm{k}_{\mathrm{z}}}$ in $\mathrm{a}=\mathrm{e}^{\mathrm{i} \pi \mathrm{k}_{\mathrm{z}}}$. Therefore, the two lines which are written above are not contradictory and the solution is:

$$
\begin{array}{llll}
\mathrm{s}_{1 \mathrm{x}}^{\mathrm{k}}=0 & \mathrm{~s}_{2 \mathrm{x}}^{\mathrm{k}}=0 & \mathrm{~s}_{3 \mathrm{x}}^{\mathrm{k}}=0 & \mathrm{~s}_{4 \mathrm{x}}^{\mathrm{k}}=0 \\
\mathrm{~s}_{1 \mathrm{y}}^{\mathrm{k}}=\lambda \mathrm{e}^{\mathrm{i} \alpha} & \mathrm{s}_{2 \mathrm{y}}^{\mathrm{k}}=-\lambda \mathrm{e}^{\mathrm{i} \alpha} \mathrm{e}^{-\mathrm{i} \pi \mathrm{k}_{\mathrm{z}}} & \mathrm{s}_{3 \mathrm{y}}^{\mathrm{k}}=\lambda \mathrm{e}^{-\mathrm{i} \alpha} & \mathrm{s}_{4 \mathrm{y}}^{\mathrm{k}}=-\lambda \mathrm{e}^{-\mathrm{i} \alpha} \mathrm{e}^{-\mathrm{i} \pi \mathrm{k}_{\mathrm{z}}} \\
\mathrm{s}_{1 \mathrm{z}}^{\mathrm{k}}=0 & \mathrm{~s}_{2 \mathrm{z}}^{\mathrm{k}}=0 & \mathrm{~s}_{3 \mathrm{z}}^{\mathrm{k}}=0 & \mathrm{~s}_{4 \mathrm{z}}^{\mathrm{k}}=0
\end{array}
$$

where $\lambda$ is a real quantity. 


\section{EPJ Web of Conferences}

The corresponding magnetic moments are along the y axis and are given by formula $\left(1^{\prime}\right)$, adding the Fourier components and their complex conjugate:

$$
\begin{aligned}
& \mathrm{m}_{1 \mathrm{y}}(R)=2 \lambda \cos \left(2 \pi \mathrm{k}_{\mathrm{z}} \mathrm{R}_{\mathrm{z}}-\alpha\right) \\
& \mathrm{m}_{2 \mathrm{y}}(R)=-2 \lambda \cos \left(2 \pi \mathrm{k}_{\mathrm{z}} \mathrm{R}_{\mathrm{z}}+\pi \mathrm{k}_{\mathrm{z}}-\alpha\right) \\
& \mathrm{m}_{3 \mathrm{y}}(R)=2 \lambda \cos \left(2 \pi \mathrm{k}_{\mathrm{z}} \mathrm{R}_{\mathrm{z}}+\alpha\right) \\
& \mathrm{m}_{4 \mathrm{y}}(R)=-2 \lambda \cos \left(2 \pi \mathrm{k}_{\mathrm{z}} \mathrm{R}_{\mathrm{z}}+\pi \mathrm{k}_{\mathrm{z}}+\alpha\right)
\end{aligned}
$$

For the magnetic structure corresponding to this irreducible co-representation, there are two quantities to be determined experimentally: the amplitude of the modulated moments $2 \lambda$ and the phase difference $2 \alpha$ between the moments of atoms $\operatorname{Pr}_{3}$ and $\operatorname{Pr}_{1}$ (as well as between atoms $\operatorname{Pr}_{4}$ and $\operatorname{Pr}_{2}$ ). $\operatorname{The}$ phase difference between atoms atoms $\operatorname{Pr}_{2}$ and $\operatorname{Pr}_{1}$ (as well as between atoms $\operatorname{Pr}_{4}$ and $\operatorname{Pr}_{3}$ ) is determined by the propagation vector of the magnetic structure. Before the use of co-representations, there remained 3 parameters to be determined: 2 lengths and one phase.

For co-representation $\mathrm{c} \tau_{1}^{-}$:

We get the following equalities:

$$
\begin{aligned}
& s_{1 y}^{k}=-a s_{2 y}^{k}=-s_{3 y}^{* k}=a s_{4 y}^{* k} \\
& s_{1 y}^{* k}=-a s_{2 y}^{* k}=-s_{3 y}^{k}=a s_{4 y}^{k}
\end{aligned}
$$

which provide the following components:

$$
\begin{array}{llll}
\mathrm{s}_{1 \mathrm{x}}^{\mathrm{k}}=0 & \mathrm{~s}_{2 \mathrm{x}}^{\mathrm{k}}=0 & \mathrm{~s}_{3 \mathrm{x}}^{\mathrm{k}}=0 & \mathrm{~s}_{4 \mathrm{x}}^{\mathrm{k}}=0 \\
\mathrm{~s}_{1 \mathrm{y}}^{\mathrm{k}}=\lambda \mathrm{e}^{\mathrm{i} \beta} & \mathrm{s}_{2 \mathrm{y}}^{\mathrm{k}}=-\lambda \mathrm{e}^{\mathrm{i} \beta} \mathrm{e}^{-\mathrm{i} \pi \mathrm{k}_{\mathrm{z}}} & \mathrm{s}_{3 \mathrm{y}}^{\mathrm{k}}=-\lambda \mathrm{e}^{-\mathrm{i} \beta} & \mathrm{s}_{4 \mathrm{y}}^{\mathrm{k}}=\lambda \mathrm{e}^{-\mathrm{i} \beta} \mathrm{e}^{-\mathrm{i} \pi \mathrm{k}_{\mathrm{z}}} \\
\mathrm{s}_{1 \mathrm{z}}^{\mathrm{k}}=0 & \mathrm{~s}_{2 \mathrm{z}}^{\mathrm{k}}=0 & \mathrm{~s}_{3 \mathrm{z}}^{\mathrm{k}}=0 & \mathrm{~s}_{4 \mathrm{z}}^{\mathrm{k}}=0
\end{array}
$$

These components correspond to the same solution as that provided by co-representation $\mathrm{c} \tau_{1^{+}}$: both solutions differ only by a phase factor, which can be seen in writing $\beta=\alpha+\pi / 2$. This will be true, with the same phase difference, for all the solutions corresponding to co-representations $\mathrm{c} \tau_{v}^{+}$and $\mathrm{c} \tau_{v}^{-}$, illustrating the equivalence between these co-representations.

For co-representation $\mathrm{c} \tau_{2}^{+}$:

We get the following equalities:

$$
\begin{aligned}
& \mathrm{s}_{1 \mathrm{x}}^{\mathrm{k}}=-\mathrm{as}_{2 \mathrm{x}}^{\mathrm{k}}=\mathrm{s}_{3 \mathrm{x}}^{* \mathrm{k}}=-\mathrm{as}_{4 \mathrm{x}}^{* \mathrm{k}} \\
& \mathrm{s}_{1 \mathrm{z}}^{\mathrm{k}}=\mathrm{as}_{2 \mathrm{z}}^{\mathrm{k}}=\mathrm{s}_{3 \mathrm{z}}^{* \mathrm{k}}=\mathrm{as}_{4 \mathrm{z}}^{* \mathrm{k}}
\end{aligned}
$$

which provide the following components:

$$
\begin{array}{llll}
\mathrm{s}_{1 \mathrm{x}}^{\mathrm{k}}=\lambda \mathrm{e}^{\mathrm{i} \alpha} & \mathrm{s}_{2 \mathrm{x}}^{\mathrm{k}}=-\lambda \mathrm{e}^{\mathrm{i} \alpha} \mathrm{e}^{-\mathrm{i} \pi \mathrm{k}_{\mathrm{z}}} & \mathrm{s}_{3 \mathrm{x}}^{\mathrm{k}}=\lambda \mathrm{e}^{-\mathrm{i} \alpha} & \mathrm{s}_{4 \mathrm{x}}^{\mathrm{k}}=-\lambda \mathrm{e}^{-\mathrm{i} \alpha} \mathrm{e}^{-\mathrm{i} \pi \mathrm{k}_{\mathrm{z}}} \\
\mathrm{s}_{1 \mathrm{y}}^{\mathrm{k}}=0 & \mathrm{~s}_{2 \mathrm{y}}^{\mathrm{k}}=0 & \mathrm{~s}_{3 \mathrm{y}}^{\mathrm{k}}=0 & \mathrm{~s}_{4 \mathrm{y}}^{\mathrm{k}}=0 \\
\mathrm{~s}_{1 \mathrm{z}}^{\mathrm{k}}=\mu \mathrm{e}^{\mathrm{i} \beta} & \mathrm{s}_{2 \mathrm{z}}^{\mathrm{k}}=\mu \mathrm{e}^{\mathrm{i} \beta} \mathrm{e}^{-\mathrm{i} \pi \mathrm{k}_{\mathrm{z}}} & \mathrm{s}_{3 \mathrm{z}}^{\mathrm{k}}=\mu \mathrm{e}^{-\mathrm{i} \beta} & \mathrm{s}_{4 \mathrm{z}}^{\mathrm{k}}=\mu \mathrm{e}^{-\mathrm{i} \beta} \mathrm{e}^{-\mathrm{i} \pi \mathrm{k}_{\mathrm{z}}}
\end{array}
$$

with $\lambda$ and $\mu$ real. The magnetic moments are then:

$$
\begin{array}{ll}
\mathrm{m}_{1 \mathrm{x}}(\mathbf{R})=2 \lambda \cos \left(2 \pi \mathrm{k}_{\mathrm{z}} \mathrm{R}_{\mathrm{z}}-\alpha\right) & \mathrm{m}_{1 \mathrm{z}}(\mathbf{R})=2 \mu \cos \left(2 \pi \mathrm{k}_{\mathrm{z}} \mathrm{R}_{\mathrm{z}}-\beta\right) \\
\mathrm{m}_{2 \mathrm{x}}(\mathbf{R})=-2 \lambda \cos \left(2 \pi \mathrm{k}_{\mathrm{z}} \mathrm{R}_{\mathrm{z}}+\pi \mathrm{k}_{\mathrm{z}}-\alpha\right) & \mathrm{m}_{2 \mathrm{z}}(\mathbf{R})=2 \mu \cos \left(2 \pi \mathrm{k}_{\mathrm{z}} \mathrm{R}_{\mathrm{z}}+\pi \mathrm{k}_{\mathrm{z}}-\beta\right) \\
\mathrm{m}_{3 \mathrm{x}}(\mathbf{R})=2 \lambda \cos \left(2 \pi \mathrm{k}_{\mathrm{z}} \mathrm{R}_{\mathrm{z}}+\alpha\right) & \mathrm{m}_{3 \mathrm{z}}(\mathbf{R})=2 \mu \cos \left(2 \pi \mathrm{k}_{\mathrm{z}} \mathrm{R}_{\mathrm{z}}+\beta\right) \\
\mathrm{m}_{4 \mathrm{x}}(\mathbf{R})=-2 \lambda \cos \left(2 \pi \mathrm{k}_{\mathrm{z}} \mathrm{R}_{\mathrm{z}}+\pi \mathrm{k}_{\mathrm{z}}+\alpha\right) & \mathrm{m}_{4 \mathrm{z}}(\mathbf{R})=2 \mu \cos \left(2 \pi \mathrm{k}_{\mathrm{z}} \mathrm{R}_{\mathrm{z}}+\pi \mathrm{k}_{\mathrm{z}}+\beta\right)
\end{array}
$$

If the structure belongs to this irreducible representation, there will be 4 parameters to be determined experimentally: the amplitudes of the $\mathrm{x}$ and the $\mathrm{z}$ components of the magnetic moments $2 \lambda$ and $2 \mu$ and 


\section{Contribution of Symmetries in Condensed Matter}

also the phase differences $2 \alpha$ between the $\mathrm{x}$ components of the magnetic moments of atoms $\operatorname{Pr}_{3}$ and $\operatorname{Pr}_{1}$ and $2 \beta$ between the $\mathrm{z}$ components of the same atoms, these two phases being different a priori. Before using the co-representations, 7 parameters remained to be determined: 4 lengths and 3 phases.

The magnetic structures corresponding to co-representations $\mathrm{c} \tau_{3}$ and $\mathrm{c} \tau_{4}$ are the same as those of $\mathrm{c} \tau_{2}$ and $\mathrm{c} \tau_{1}$, but with a change of sign in the couplings.

\section{THE USEFULNESS OF CO-REPRESENTATIONS: OTHER EXAMPLES}

From the 3 cases of irreducible co-representations listed above, case (b) is very rare. We shall give very simple examples of cases (a) and (c) to demonstrate the information that can be brought by co-representations.

\section{VII.1 Helices in an acentric tetragonal group (Fedorov group)}

Let us consider one magnetic atom at the origin of the cell of space group P4 (space group $\mathrm{n}^{\circ} 75$ ), with a propagation vector $\mathbf{k}=\left(0,0, \mathrm{k}_{z}\right)$. The space group contains 4 symmetry elements: $\mathrm{h}_{1}(\mathrm{x}, \mathrm{y}, \mathrm{z}), \mathrm{h}_{4}(-\mathrm{x},-\mathrm{y}, \mathrm{z})$, $\mathrm{h}_{14}(-\mathrm{y}, \mathrm{x}, \mathrm{z})$ and $\mathrm{h}_{15}(\mathrm{y},-\mathrm{x}, \mathrm{z})$ according to Kovalev's notations [5].

As there is no vector $-\mathbf{k}$ in the $\operatorname{star}\{\mathbf{k}\}$ (acentric structure), there is no $h_{0}$ operator in the space group and $\mathrm{M}_{\mathrm{k}}=\mathrm{G}_{\mathrm{k}}$. The possible magnetic structures can be predicted by the representation analysis only. No co-representation treatment is possible.

Contrarily to the working example of PrPtAl, we shall use here and in the following examples the passive operator approach that is the action of the operators on the basis vectors $\mathbf{e}_{j \alpha}$. The following table figures out the action of the 4 operators $h_{1}, h_{4}, h_{14}$ and $h_{15}$ on the basis vectors of the magnetic moment of the unique magnetic atom of the cell, as well as the character of the natural representation $\Gamma_{\mathrm{k}}$.

\begin{tabular}{|l|c|c|c|c|}
\hline $\begin{array}{l}\text { Basis } \\
\text { vector }\end{array}$ & $\begin{array}{c}\mathrm{h}_{1} \\
(\mathrm{x}, \mathrm{y}, \mathrm{z})\end{array}$ & $\begin{array}{c}\mathrm{h}_{4} \\
(-\mathrm{x},-\mathrm{y}, \mathrm{z})\end{array}$ & $\begin{array}{c}\mathrm{h}_{14} \\
(-\mathrm{y}, \mathrm{x}, \mathrm{z})\end{array}$ & $\begin{array}{c}\mathrm{h}_{15} \\
(\mathrm{y},-\mathrm{x}, \mathrm{z})\end{array}$ \\
\hline $\mathbf{e}_{\mathrm{x}}^{\mathrm{k}}$ & $\mathbf{e}_{\mathrm{x}}^{\mathrm{k}}$ & $-\mathbf{e}_{\mathrm{x}}^{\mathrm{k}}$ & $\mathbf{e}_{\mathrm{y}}^{\mathrm{k}}$ & $-\mathbf{e}_{\mathrm{y}}^{\mathrm{k}}$ \\
\hline $\mathbf{e}_{\mathrm{y}}^{\mathrm{k}}$ & $\mathbf{e}_{\mathrm{y}}^{\mathrm{k}}$ & $-\mathbf{e}_{\mathrm{y}}^{\mathrm{k}}$ & $-\mathbf{e}_{\mathrm{x}}^{\mathrm{k}}$ & $\mathbf{e}_{\mathrm{x}}^{\mathrm{k}}$ \\
\hline $\mathbf{e}_{\mathrm{z}}^{\mathrm{k}}$ & $\mathbf{e}_{\mathrm{z}}^{\mathrm{k}}$ & $\mathbf{e}_{\mathrm{z}}^{\mathrm{k}}$ & $\mathbf{e}_{\mathrm{z}}^{\mathrm{k}}$ & $\mathbf{e}_{\mathrm{z}}^{\mathrm{k}}$ \\
\hline$\chi$ & 3 & -1 & 1 & 1 \\
\hline
\end{tabular}

The next table shows the irreducible representations, as taken from ref [5].

\begin{tabular}{|l|c|c|c|c|}
\hline Representation & $\mathrm{h}_{1}$ & $\mathrm{~h}_{4}$ & $\mathrm{~h}_{14}$ & $\mathrm{~h}_{15}$ \\
\hline$\tau_{1}$ & 1 & 1 & 1 & 1 \\
\hline$\tau_{2}$ & 1 & -1 & $\mathrm{i}$ & $-\mathrm{i}$ \\
\hline$\tau_{3}$ & 1 & 1 & -1 & -1 \\
\hline$\tau_{4}$ & 1 & -1 & $-\mathrm{i}$ & $\mathrm{i}$ \\
\hline
\end{tabular}

The decomposition of the natural representation of the basis vectors is:

$$
\Gamma=\tau_{1}+\tau_{2}+\tau_{4}
$$

The application of the projection operators on the 3 subspaces corresponding to the 3 irreducible representations yields the 3 new basis vectors:

$$
\text { for } \tau_{1} \quad \mathbf{E}_{1}=\mathbf{e}_{\mathrm{z}}^{\mathrm{k}}
$$

and as the solution is one-dimensional, the most general answer is any vector parallel to $\mathbf{E}_{1}$ $\mathbf{s}^{\mathrm{k}}=\mathrm{me}^{\mathrm{i} \varphi} \mathbf{E}_{1}=\mathrm{me}^{\mathrm{i} \varphi} \mathbf{e}_{\mathrm{z}}^{\mathrm{k}}$

$$
\text { for } \tau_{2} \quad \mathbf{E}_{2}=\mathbf{e}_{\mathrm{x}}^{\mathrm{k}}+\mathbf{i e}_{\mathrm{y}}^{\mathrm{k}}
$$


with the general solution $\mathbf{s}^{\mathrm{k}}=\mathrm{me}^{\mathrm{i} \varphi} \mathbf{E}_{4}=\mathrm{me}^{\mathrm{i} \varphi}\left(\mathbf{e}_{\mathrm{x}}^{\mathrm{k}}+\mathrm{ie}_{\mathrm{y}}^{\mathrm{k}}\right)$

$$
\text { for } \tau_{4} \quad \mathbf{E}_{4}=\mathbf{e}_{\mathrm{x}}^{\mathrm{k}}-\mathrm{i} \mathbf{e}_{\mathrm{y}}^{\mathrm{k}}
$$

with the general solution $\mathbf{s}^{\mathrm{k}}=\mathrm{me}^{\mathrm{i} \varphi} \mathbf{E}_{4}=\mathrm{me}^{\mathrm{i} \varphi}\left(\mathbf{e}_{\mathrm{x}}^{\mathrm{k}}+\mathrm{i} \mathbf{e}_{\mathrm{y}}^{\mathrm{k}}\right)$

Coming back to the real magnetic moments $\mathbf{m}(\mathbf{R})$ in all the cells of the crystal, using formula ( $\left.1^{\prime}\right)$, there are 3 structures compatible with the spatial symmetries:

for $\tau_{1}$,

a modulated structure

$\mathbf{m}(\mathbf{R})=2 \mathbf{m e}_{\mathrm{z}}^{\mathrm{k}} \cos (\mathbf{k} \mathbf{R}-\varphi)$

for $\tau_{2}$,

an helicoidal structure

$$
\mathbf{m}(\mathbf{R})=2 \mathrm{~m}\left[\mathbf{e}_{\mathrm{x}}^{\mathrm{k}} \cos (\mathbf{k} \mathbf{R}-\varphi)-\mathbf{e}_{\mathrm{y}}^{\mathrm{k}} \sin (\mathbf{k} \mathbf{R}-\varphi)\right]
$$

for $\tau_{4}$,

an helicoidal structure with the opposed chirality $\quad \mathbf{m}(\mathbf{R})=2 \mathrm{~m}\left[\mathrm{e}_{\mathrm{x}}^{\mathrm{k}} \cos (\mathbf{k} \mathbf{R}-\varphi)+\mathbf{e}_{\mathrm{y}}^{\mathrm{k}} \sin (\mathbf{k R}-\varphi)\right]$

These three structures, and particularly the two helices, corresponding to different irreducible representations, are not supposed to have the same magnetic energy and are not degenerate.

\section{VII.2 Helices in a centric tetragonal group (black and white, cases a and c)}

We consider now the same magnetic atom at the origin of the cell but in the space group P4/m (space group $\mathrm{n}^{\circ} 83$ ), with the same propagation vector $\mathbf{k}=\left(0,0, \mathrm{k}_{\mathrm{z}}\right)$. The space group contains now 8 symmetry elements: as before $\mathrm{h}_{1}(\mathrm{x}, \mathrm{y}, \mathrm{z}), \mathrm{h}_{4}(-\mathrm{x},-\mathrm{y}, \mathrm{z}), \mathrm{h}_{14}(-\mathrm{y}, \mathrm{x},-\mathrm{z})$ and $\mathrm{h}_{15}(\mathrm{y},-\mathrm{x}, \mathrm{z})$, but also the 4 operators resulting from the presence of the inversion operator : $\mathrm{h}_{25}(-\mathrm{x},-\mathrm{y},-\mathrm{z}), \mathrm{h}_{28}(\mathrm{x}, \mathrm{y},-\mathrm{z}), \mathrm{h}_{38}(\mathrm{y},-\mathrm{x},-\mathrm{z})$ and $\mathrm{h}_{39}(-\mathrm{y}, \mathrm{x},-\mathrm{z})$.

Here, the structure is centric: $-\mathbf{k}$ belongs to the star $\{\mathbf{k}\}$. The little group $G_{k}$ is restricted to the 4 operators $h_{1}, h_{4}, h_{14}$ and $h_{15}$, as in the former case for the acentric structure. But, when including conjugation, the magnetic little group $\mathrm{M}_{\mathrm{k}}=\mathrm{G}_{\mathrm{k}}+\mathrm{Ch}_{25} \mathrm{G}_{\mathrm{k}}$ is black and white: it contains now 8 elements, with the reversing element $\mathrm{Ch}_{25}$.

The next table shows the action of the 8 elements $\mathrm{h}_{1}, \mathrm{~h}_{4}, \mathrm{~h}_{14}, \mathrm{~h}_{15}, \mathrm{Ch}_{25}, \mathrm{Ch}_{28}, \mathrm{Ch}_{38}$ and $\mathrm{Ch}_{39}$ on the

\begin{tabular}{|c|c|c|c|c|c|c|c|c|}
\hline $\begin{array}{l}\text { Basis } \\
\text { vector }\end{array}$ & $\begin{array}{c}\mathrm{h}_{1} \\
(\mathrm{x}, \mathrm{y}, \mathrm{z})\end{array}$ & $\begin{array}{c}\mathrm{h}_{4} \\
(-\mathrm{x},-\mathrm{y}, \mathrm{z})\end{array}$ & $\begin{array}{c}\mathrm{h}_{14} \\
(-\mathrm{y}, \mathrm{x}, \mathrm{z})\end{array}$ & $\begin{array}{c}\mathrm{h}_{15} \\
(\mathrm{y},-\mathrm{x}, \mathrm{z})\end{array}$ & $\begin{array}{c}\mathrm{Ch}_{25} \\
(-\mathrm{x},-\mathrm{y},-\mathrm{z})\end{array}$ & $\begin{array}{c}\mathrm{Ch}_{28} \\
(\mathrm{x}, \mathrm{y},-\mathrm{z})\end{array}$ & $\begin{array}{c}\mathrm{Ch}_{38} \\
(\mathrm{y},-\mathrm{x},-\mathrm{z})\end{array}$ & $\begin{array}{c}\mathrm{Ch}_{39} \\
(-\mathrm{y}, \mathrm{x},-\mathrm{z})\end{array}$ \\
\hline $\mathbf{e}_{\mathrm{x}}^{\mathrm{k}}$ & $\mathbf{e}_{\mathrm{x}}^{\mathrm{k}}$ & $-\mathbf{e}_{\mathrm{x}}^{\mathrm{k}}$ & $\mathbf{e}_{\mathrm{y}}^{\mathrm{k}}$ & $-\mathbf{e}_{\mathrm{y}}^{\mathrm{k}}$ & $\mathbf{e}_{\mathrm{x}}^{* \mathrm{k}}$ & $-\mathbf{e}_{\mathrm{x}}^{* \mathrm{k}}$ & $\mathbf{e}_{\mathrm{y}}^{* \mathrm{k}}$ & $-\mathbf{e}_{\mathrm{v}}^{* \mathrm{k}}$ \\
\hline $\mathbf{e}_{\mathrm{y}}^{\mathrm{k}}$ & $\mathbf{e}_{\mathrm{y}}^{\mathrm{k}}$ & $-\mathbf{e}_{\mathrm{y}}^{\mathrm{k}}$ & $-\mathbf{e}_{x}^{k}$ & $\mathbf{e}_{\mathrm{x}}^{\mathrm{k}}$ & $\mathbf{e}_{\mathrm{y}}^{* \mathrm{k}}$ & $-\mathbf{e}_{\mathrm{y}}^{* \mathrm{k}}$ & $-\mathbf{e}_{\mathrm{x}}^{* \mathrm{k}}$ & $\mathbf{e}_{\mathrm{x}}^{* \mathrm{k}}$ \\
\hline $\mathbf{e}_{7}^{\mathrm{k}}$ & $\mathbf{e}_{7}^{k}$ & $\mathbf{e}_{7}^{\mathrm{k}}$ & $\mathbf{e}_{7}^{\mathrm{k}}$ & $\mathbf{e}_{z}^{\mathrm{k}}$ & $\mathbf{e}_{7}^{* \mathrm{kk}}$ & $\mathbf{e}_{\mathrm{z}}^{* \mathrm{k}}$ & $\mathbf{e}_{\mathrm{7}}^{* \mathrm{k}}$ & $\mathbf{e}_{\mathrm{z}}^{* \mathrm{k}}$ \\
\hline $\mathbf{e}_{\mathrm{x}}^{* \mathrm{k}}$ & $\mathbf{e}_{\mathrm{x}}^{* \mathrm{k}}$ & $-\mathbf{e}_{\mathrm{x}}^{* \mathrm{k}}$ & $\mathbf{e}_{\mathrm{v}}^{* \mathrm{k}}$ & $-\mathbf{e}_{\mathrm{y}}^{* \mathrm{k}}$ & $\mathbf{e}_{\mathrm{x}}^{\mathrm{k}}$ & $-\mathbf{e}_{\mathrm{x}}^{\mathrm{k}}$ & $\mathbf{e}_{\mathrm{v}}^{\mathrm{k}}$ & $-\mathbf{e}_{\mathrm{v}}^{\mathrm{k}}$ \\
\hline $\mathbf{e}_{\mathrm{y}}^{* \mathrm{k}}$ & $\mathbf{e}_{\mathrm{y}}^{* k \mathrm{k}}$ & $-\mathbf{e}_{\mathrm{y}}^{* \mathrm{k}}$ & $-\mathbf{e}_{\mathrm{x}}^{* \mathrm{k}}$ & $\mathbf{e}_{\mathrm{x}}^{* \mathrm{k}}$ & $\mathbf{e}_{\mathrm{y}}^{\mathrm{k}}$ & $-\mathbf{e}_{\mathrm{y}}^{\mathrm{k}}$ & $-\mathbf{e}_{\mathrm{x}}^{\mathrm{k}}$ & $\mathbf{e}_{\mathrm{x}}^{\mathrm{k}}$ \\
\hline $\mathbf{e}_{\mathrm{z}}^{* \mathrm{k}}$ & $\mathbf{e}_{\mathrm{z}}^{* \mathrm{k}}$ & $\mathbf{e}_{\mathrm{z}}^{* K}$ & $\mathbf{e}_{\mathrm{z}}^{* \mathrm{k}}$ & $\mathbf{e}_{\mathrm{z}}^{* \mathrm{k}}$ & $\mathbf{e}_{z}^{k}$ & $\mathbf{e}_{\mathrm{z}}^{\mathrm{k}}$ & $\mathbf{e}_{\mathrm{z}}^{\mathrm{k}}$ & $\mathbf{e}_{\mathrm{z}}^{\mathrm{k}}$ \\
\hline$\chi$ & 6 & -2 & 2 & 2 & 0 & 0 & 0 & 0 \\
\hline
\end{tabular}
basis vectors $\mathbf{e}_{\alpha}^{\mathrm{k}}$ and $\mathbf{e}_{\alpha}^{* \mathrm{k}}$.

The next table figures out the irreducible co-representations of $\mathrm{M}_{\mathrm{k}}$. These values are obtained from the irreducible representations. The value taken by the $\operatorname{sum} \sum_{\mathrm{j}} \chi\left(\mathrm{a}_{\mathrm{j}}^{2}\right)$ is equal to 4 for the irreducible representations $\tau_{1}$ and $\tau_{3}$ which are of type (a), and equal to 0 for the irreducible representations $\tau_{2}$ and $\tau_{4}$ which are of type (c). Therefore the irreducible co-representations $\mathrm{c} \tau_{1}^{+}$and $\mathrm{c} \tau_{1}^{-}$are given by formulae (15) and (16) while $\tau_{2}$ and $\tau_{4}$, being of type (c), join together to give the irreducible co-representation $\mathrm{c} \tau_{2+4}$ according to formulae (18). 


\begin{tabular}{|c|c|c|c|c|c|c|c|c|}
\hline co-representation & $\mathrm{h}_{1}$ & $\mathrm{~h}_{4}$ & $\mathrm{~h}_{14}$ & $\mathrm{~h}_{15}$ & $\mathrm{Ch}_{25}$ & $\mathrm{Ch}_{28}$ & $\mathrm{Ch}_{38}$ & $\mathrm{Ch}_{39}$ \\
\hline $\mathrm{c} \tau_{1}^{+}$ & 1 & 1 & 1 & 1 & 1 & 1 & 1 & 1 \\
\hline $\mathrm{c} \tau_{1}^{-}$ & 1 & 1 & 1 & 1 & -1 & -1 & -1 & -1 \\
\hline $\mathrm{c} \tau_{3}^{+}$ & 1 & 1 & -1 & -1 & 1 & 1 & -1 & -1 \\
\hline $\mathrm{c} \tau_{3}^{-}$ & 1 & 1 & -1 & -1 & -1 & -1 & 1 & 1 \\
\hline $\mathrm{c} \tau_{2+4}$ & $\left(\begin{array}{ll}1 & 0 \\
0 & 1\end{array}\right)$ & $\left(\begin{array}{cc}-1 & 0 \\
0 & -1\end{array}\right)$ & $\left(\begin{array}{cc}\mathrm{i} & 0 \\
0 & -\mathrm{i}\end{array}\right)$ & $\left(\begin{array}{cc}-\mathrm{i} & 0 \\
0 & \mathrm{i}\end{array}\right)$ & $\left(\begin{array}{ll}0 & 1 \\
1 & 0\end{array}\right)$ & $\left(\begin{array}{cc}0 & -1 \\
-1 & 0\end{array}\right)$ & $\left(\begin{array}{cc}0 & \mathrm{i} \\
-\mathrm{i} & 0\end{array}\right)$ & $\left(\begin{array}{cc}0 & -i \\
i & 0\end{array}\right)$ \\
\hline
\end{tabular}

The decomposition of co-representation $\mathrm{c}_{\mathrm{k}}$ into irreducible co-representations is the following:

$$
\mathrm{c} \Gamma_{\mathrm{k}}=\mathrm{c} \tau_{1}^{+}+\mathrm{c} \tau_{1}^{-}+2 \mathrm{c} \tau_{2+4}
$$

In the space of complex vectors $\mathbf{e}_{\alpha}^{\mathrm{k}}$ and $\mathbf{e}_{\alpha}^{-\mathrm{k}}$, the application of the projection operators on the 3 subspaces corresponding to the 3 irreducible representations yields the new basis vectors:

$$
\begin{array}{cl}
\text { for } \mathrm{c} \tau_{1}^{+} & \mathbf{E}_{1^{+}}=\mathbf{e}_{\mathrm{z}}^{\mathrm{k}}+\mathbf{e}_{\mathrm{z}}^{* \mathrm{k}} \\
\text { for } \mathrm{c} \tau_{1}^{-} & \mathbf{E}_{1^{-}}=\mathbf{e}_{\mathrm{z}}^{\mathrm{k}}-\mathbf{e}_{\mathrm{z}}^{* \mathrm{k}} \\
\text { for } \mathrm{c} \tau_{2+3} & \mathbf{E}_{2+4}^{1}=\mathbf{e}_{\mathrm{x}}^{\mathrm{k}}+\mathrm{i} \mathbf{e}_{\mathrm{y}}^{\mathrm{k}} \\
& \mathbf{E}_{2+4}^{2}=\mathbf{e}_{\mathrm{x}}^{\mathrm{k}}-\mathrm{i} \mathbf{e}_{\mathrm{y}}^{\mathrm{k}} \\
& \mathbf{E}_{2+4}^{3}=\mathbf{e}_{\mathrm{x}}^{* \mathrm{k}}+\mathrm{i} \mathbf{e}_{\mathrm{y}}^{* \mathrm{k}} \\
& \mathbf{E}_{2+4}^{4}=\mathbf{e}_{\mathrm{x}}^{* \mathrm{k}}-\mathrm{i} \mathbf{e}_{\mathrm{y}}^{* \mathrm{k}}
\end{array}
$$

$\mathrm{c} \tau_{1}^{+}$and $\mathrm{c} \tau_{1}^{-}$give two solutions which just differ by a coefficient $\mathrm{i}$, and which provide the same modulated magnetic structure along Oz. Co-representation $\mathrm{c} \tau_{2+4}$ gives two basis vectors and their transformations (conjugation plus change of $\mathbf{k}$ in $-\mathbf{k}$ ). Each pair contains the 2 chiralities $\mathbf{u}-\mathbf{i v}$ and $\mathbf{u}+\mathbf{i v}$ in the basal plane. As in the first example, both helices are compatible with the symmetries. But in this centric case, the two helices correspond to the same irreducible co-representation: they have the same energy and may coexist in the crystal. They can also mix together to give a 2-dimension solution: the whole plane $\mathrm{xy}$.

\section{VII.3 Modulations in an orthorhombic group (black and white group, case a)}

Let us consider the space group Pmmm ( $\left.{ }^{\circ} 47\right)$ with two atoms in the unit cell: atom 1 in $(0, y, 0)$ and atom 2 in $(0,-y, 0)$. This space group contains 8 rotation (rotation-inversion) operators: $h_{1}(x, y, z), h_{2}(x,-y,-z)$, $\mathrm{h}_{3}(-\mathrm{x}, \mathrm{y},-\mathrm{z}), \mathrm{h}_{4}(-\mathrm{x},-\mathrm{y}, \mathrm{z}), \mathrm{h}_{25}(-\mathrm{x},-\mathrm{y},-\mathrm{z}), \mathrm{h}_{26}(-\mathrm{x}, \mathrm{y}, \mathrm{z}), \mathrm{h}_{27}(\mathrm{x},-\mathrm{y}, \mathrm{z})$ and $\mathrm{h}_{28}(\mathrm{x}, \mathrm{y},-\mathrm{z})$.

Below the Néel temperature, the atoms order magnetically with a propagation vector $\mathbf{k}=\left(\mathrm{k}_{\mathrm{x}}, 0,0\right)$.

VII.3.1 Let us first apply the representation analysis and restrict ourself to all the operators which keep the propagation vector unchanged. The little group $\mathrm{G}_{\mathrm{k}}$ contains 4 operators: $\mathrm{h}_{1}, \mathrm{~h}_{2}, \mathrm{~h}_{27}$ and $\mathrm{h}_{28}$. We write down the natural representation of the basis vectors in the little group $\mathrm{G}_{\mathrm{k}}$. First we write down how the 4 rotation (or rotation-inversion) operators of $G_{k}$ transform one atomic position in the other position. 


\section{EPJ Web of Conferences}

\begin{tabular}{|l|c|c|c|c|}
\hline atom & $\begin{array}{c}\mathrm{h}_{1} \\
(\mathrm{x}, \mathrm{y}, \mathrm{z})\end{array}$ & $\begin{array}{c}\mathrm{h}_{2} \\
(\mathrm{x},-\mathrm{y},-\mathrm{z})\end{array}$ & $\begin{array}{c}\mathrm{h}_{27} \\
(\mathrm{x},-\mathrm{y}, \mathrm{z})\end{array}$ & $\begin{array}{c}\mathrm{h}_{28} \\
(\mathrm{x}, \mathrm{y},-\mathrm{z})\end{array}$ \\
\hline atom 1 & atom 1 & atom 2 & atom 2 & atom 1 \\
\hline atom 2 & atom 2 & atom 1 & atom 1 & atom 2 \\
\hline
\end{tabular}

Then we write the action of the operators on the components of the basis vectors $\mathbf{e}_{j \alpha}^{\mathrm{k}}$. We have to remind here that we deal with pseudo-vectors (axial vectors): $h_{1}$ and $h_{2}$ are proper operators while $h_{27}$ and $\mathrm{h}_{28}$ are improper.

\begin{tabular}{lcccc}
\hline Basis vector & $\begin{array}{c}\mathrm{h}_{1} \\
(\mathrm{x}, \mathrm{y}, \mathrm{z})\end{array}$ & $\begin{array}{c}\mathrm{h}_{2} \\
(\mathrm{x},-\mathrm{y},-\mathrm{z})\end{array}$ & $\begin{array}{c}\mathrm{h}_{27} \\
(\mathrm{x},-\mathrm{y}, \mathrm{z})\end{array}$ & $\begin{array}{c}\mathrm{h}_{28} \\
(\mathrm{x}, \mathrm{y},-\mathrm{z})\end{array}$ \\
\hline $\mathbf{e}_{1 \mathrm{x}}^{\mathrm{k}}$ & $\mathbf{e}_{1 \mathrm{x}}^{\mathrm{k}}$ & $\mathbf{e}_{2 \mathrm{x}}^{\mathrm{k}}$ & $-\mathbf{e}_{2 \mathrm{x}}^{\mathrm{k}}$ & $-\mathbf{e}_{1 \mathrm{x}}^{\mathrm{k}}$ \\
$\mathbf{e}_{1 \mathrm{y}}^{\mathrm{k}}$ & $\mathbf{e}_{1 \mathrm{y}}^{\mathrm{k}}$ & $-\mathbf{e}_{2 \mathrm{y}}^{\mathrm{k}}$ & $\mathbf{e}_{2 \mathrm{y}}^{\mathrm{k}}$ & $-\mathbf{e}_{1 \mathrm{y}}^{\mathrm{k}}$ \\
$\mathbf{e}_{1 \mathrm{y}}^{\mathrm{k}}$ & $\mathbf{e}_{1 \mathrm{z}}^{\mathrm{k}}$ & $-\mathbf{e}_{2 \mathrm{z}}^{\mathrm{k}}$ & $-\mathbf{e}_{2 \mathrm{z}}^{\mathrm{k}}$ & $\mathbf{e}_{1 \mathrm{z}}^{\mathrm{k}}$ \\
$\mathbf{e}_{2 \mathrm{x}}^{\mathrm{k}}$ & $\mathbf{e}_{2 \mathrm{x}}^{\mathrm{k}}$ & $\mathbf{e}_{1 \mathrm{x}}^{\mathrm{k}}$ & $-\mathbf{e}_{1 \mathrm{x}}^{\mathrm{k}}$ & $-\mathbf{-}_{2 \mathrm{x}}^{\mathrm{k}}$ \\
$\mathbf{e}_{2 \mathrm{y}}^{\mathrm{k}}$ & $\mathbf{e}_{2 \mathrm{y}}^{\mathrm{k}}$ & $-\mathbf{e}_{1 \mathrm{y}}^{\mathrm{k}}$ & $\mathbf{e}_{1 \mathrm{y}}^{\mathrm{k}}$ & $-\mathbf{e}_{2 \mathrm{y}}^{\mathrm{k}}$ \\
$\mathbf{e}_{2 \mathrm{z}}^{\mathrm{k}}$ & $\mathbf{e}_{2 \mathrm{z}}^{\mathrm{k}}$ & $-\mathbf{e}_{1 \mathrm{z}}^{\mathrm{k}}$ & $-\mathbf{e}_{1 \mathrm{z}}^{\mathrm{k}}$ & $\mathbf{e}_{2 \mathrm{z}}^{\mathrm{k}}$ \\
$\chi\left(\Gamma_{\mathrm{k}}\right)$ & 6 & 0 & 0 & -2 \\
\hline
\end{tabular}

We take in Kovalev's text books [5] the following table for the irreducible representations: There are all of order 1.

\begin{tabular}{|l|c|c|c|c|}
\hline Irrep & $\mathrm{h}_{1}$ & $\mathrm{~h}_{2}$ & $\mathrm{~h}_{27}$ & $\mathrm{~h}_{28}$ \\
\hline$\tau_{1}$ & 1 & 1 & 1 & 1 \\
\hline$\tau_{2}$ & 1 & 1 & -1 & -1 \\
\hline$\tau_{3}$ & 1 & -1 & 1 & -1 \\
\hline$\tau_{4}$ & 1 & -1 & -1 & 1 \\
\hline
\end{tabular}

We now reduce the natural representations $\Gamma_{\mathrm{k}}$ in its irreducible representations $\tau_{\nu}$. The number of times each $\tau_{v}$ appears in the reduction is given by $\mathrm{a}_{v}=\frac{1}{\mathrm{~g}} \sum_{\mathrm{i}}\left[\chi_{\tau_{v}}\left(\mathrm{~h}_{\mathrm{i}} \mid \mathbf{v}_{\mathrm{i}}\right)\right]^{*} \chi_{\Gamma_{\mathrm{k}}}\left(\mathrm{h}_{\mathrm{i}} \mid \mathbf{v}_{\mathrm{i}}\right)$, which leads to the following reduction:

$$
\Gamma_{\mathrm{k}}=\tau_{1}+2 \tau_{2}+2 \tau_{3}+\tau_{4}
$$

We get all the new basis vectors by applying the projection operator $\mathrm{P}^{v}=\sum_{\mathrm{i}}\left[\tau_{\nu}\left(\mathrm{h}_{\mathrm{i}} \mid \mathbf{v}_{\mathrm{i}}\right)\right]^{*} \Gamma_{\mathrm{k}}\left(\mathrm{h}_{\mathrm{i}} \mid \mathbf{v}_{\mathrm{i}}\right)$ to all the old basis vectors, and we obtain the new basis vectors:

For representation $\tau_{1}$

$$
\mathbf{E}_{1}=\mathbf{e}_{1 \mathrm{z}}^{\mathrm{k}}-\mathbf{e}_{2 \mathrm{z}}^{\mathrm{k}}
$$

which means a sinusoid which propagates along Ox, with the moments along $\mathrm{Oz}$ of atoms 1 and 2 equal and opposed to each other. In such a structure there remains one parameter to be determined experimentally: the length of the moments.

For representation $\tau_{2}$

$$
\begin{aligned}
& \mathbf{E}_{2}^{1}=\mathbf{e}_{1 \mathrm{x}}^{\mathrm{k}}+\mathbf{e}_{2 \mathrm{x}}^{\mathrm{k}} \\
& \mathbf{E}_{2}^{2}=\mathbf{e}_{1 \mathrm{y}}^{\mathrm{k}}-\mathbf{e}_{2 \mathrm{y}}^{\mathrm{k}}
\end{aligned}
$$

which means that the $\mathrm{x}$ components of atoms 1 and 2 are equal and parallel while the $\mathrm{y}$ components are equal and opposed. Three parameters remain to be determined experimentally: the values of the 2 components and the phase difference between them. 


\section{Contribution of Symmetries in Condensed Matter}

For representation $\tau_{3}$

$$
\begin{aligned}
& \mathbf{E}_{3}^{1}=\mathbf{e}_{1 \mathrm{x}}^{\mathrm{k}}-\mathbf{e}_{2 \mathrm{x}}^{\mathrm{k}} \\
& \mathbf{E}_{3}^{2}=\mathbf{e}_{1 \mathrm{y}}^{\mathrm{k}}+\mathbf{e}_{2 \mathrm{y}}^{\mathrm{k}}
\end{aligned}
$$

For representation $\tau_{4}$

$$
\mathbf{E}_{4}=\mathbf{e}_{1 \mathrm{z}}^{\mathrm{k}}+\mathbf{e}_{2 \mathrm{z}}^{\mathrm{k}}
$$

The magnetic structures for $\tau_{3}$ and $\tau_{4}$ are the same as those of $\tau_{2}$ and $\tau_{1}$ with a change of sign in the coupling between the atoms 1 and 2 .

\section{VII.4 Let us now introduce the conjugation operator and use the co-representations}

The magnetic little group is black and white: $M_{k}=G_{k}+C h_{25} G_{k}$ with the reversing element $\mathrm{a}_{0}=\mathrm{Ch}_{25}$ where $\mathrm{h}_{25}$ is the inversion operator $(-\mathrm{x},-\mathrm{y},-\mathrm{z})$. This group has now 8 elements: $\mathrm{h}_{1}, \mathrm{~h}_{2}, \mathrm{~h}_{27}, \mathrm{~h}_{28}$, $\mathrm{Ch}_{25}, \mathrm{Ch}_{25} \mathrm{~h}_{2}=\mathrm{Ch}_{26}, \mathrm{Ch}_{25} \mathrm{~h}_{27}=\mathrm{Ch}_{3}$ and $\mathrm{Ch}_{25} \mathrm{~h}_{28}=\mathrm{Ch}_{4}$.

We first write down the action of all the operators on the permutation of atoms 1 and 2.

\begin{tabular}{|l|c|c|c|c|c|c|c|c|}
\hline atom & $\begin{array}{c}\mathrm{h}_{1} \\
(\mathrm{x}, \mathrm{y}, \mathrm{z})\end{array}$ & $\begin{array}{c}\mathrm{h}_{2} \\
(\mathrm{x},-\mathrm{y},-\mathrm{z})\end{array}$ & $\begin{array}{c}\mathrm{h}_{27} \\
(\mathrm{x},-\mathrm{y}, \mathrm{z})\end{array}$ & $\begin{array}{c}\mathrm{h}_{28} \\
(\mathrm{x}, \mathrm{y},-\mathrm{z})\end{array}$ & $\begin{array}{c}\mathrm{Ch}_{25} \\
(-\mathrm{x},-\mathrm{y},-\mathrm{z})\end{array}$ & $\begin{array}{c}\mathrm{Ch}_{26} \\
(-\mathrm{x}, \mathrm{y}, \mathrm{z})\end{array}$ & $\begin{array}{c}\mathrm{Ch}_{3} \\
(-\mathrm{x}, \mathrm{y},-\mathrm{z})\end{array}$ & $\begin{array}{c}\mathrm{Ch}_{4} \\
(-\mathrm{x},-\mathrm{y}, \mathrm{z})\end{array}$ \\
\hline atom 1 & atom 1 & atom 2 & atom 2 & atom 1 & atom 2 & atom 1 & atom 1 & atom 2 \\
\hline atom 2 & atom 2 & atom 1 & atom 1 & atom 2 & atom 1 & atom 2 & atom 2 & atom 1 \\
\hline
\end{tabular}

Then we want to figure out the natural co-representation $\mathrm{c} \Gamma_{\mathrm{k}}$ which expresses the action of all the

\begin{tabular}{|c|c|c|c|c|c|c|c|c|}
\hline $\begin{array}{l}\text { Basis } \\
\text { vector }\end{array}$ & $\begin{array}{c}\mathrm{h}_{1} \\
(\mathrm{x}, \mathrm{y}, \mathrm{z})\end{array}$ & $\begin{array}{c}\mathrm{h}_{2} \\
(\mathrm{x},-\mathrm{y},-\mathrm{z})\end{array}$ & $\begin{array}{c}\mathrm{h}_{27} \\
(\mathrm{x},-\mathrm{y}, \mathrm{z})\end{array}$ & $\begin{array}{c}\mathrm{h}_{28} \\
(\mathrm{x}, \mathrm{y},-\mathrm{z})\end{array}$ & $\begin{array}{c}\mathrm{Ch}_{25} \\
(-\mathrm{x},-\mathrm{y},-\mathrm{z})\end{array}$ & $\begin{array}{c}\mathrm{Ch}_{26} \\
(-\mathrm{x}, \mathrm{y}, \mathrm{z})\end{array}$ & $\begin{array}{c}\mathrm{Ch}_{3} \\
(-\mathrm{x}, \mathrm{y},-\mathrm{z})\end{array}$ & $\begin{array}{c}\mathrm{Ch}_{4} \\
(-\mathrm{x},-\mathrm{y}, \mathrm{z})\end{array}$ \\
\hline $\mathbf{e}_{1 \mathrm{x}}^{\mathrm{k}}$ & $\mathbf{e}_{1 \mathrm{x}}^{\mathrm{k}}$ & $\mathbf{e}_{2 \mathrm{x}}^{\mathrm{k}}$ & $-\mathbf{e}_{2 \mathrm{x}}^{\mathrm{k}}$ & $-\mathbf{e}_{1 \mathrm{x}}^{\mathrm{k}}$ & $\mathbf{e}_{2 \mathrm{x}}^{* \mathrm{k}}$ & $\mathbf{e}_{1 \mathrm{x}}^{* \mathrm{k}}$ & $-\mathbf{e}_{1 \mathrm{x}}^{* \mathrm{k}}$ & $-\mathbf{e}_{2 \mathrm{x}}^{* \mathrm{k}}$ \\
\hline $\mathbf{e}_{1 \mathrm{y}}^{\mathrm{k}}$ & $\mathbf{e}_{1 \mathrm{y}}^{\mathrm{k}}$ & $-\mathbf{e}_{2 y}^{k}$ & $\mathbf{e}_{2 \mathrm{y}}^{\mathrm{k}}$ & $-\mathbf{e}_{1 \mathrm{y}}^{\mathrm{k}}$ & $\mathbf{e}_{2 \mathrm{y}}^{* \mathrm{k}}$ & $-\mathbf{e}_{1 \mathrm{y}}^{* \mathrm{k}}$ & $\mathbf{e}_{1 \mathrm{y}}^{* \mathrm{k}}$ & $-\mathbf{e}_{2 \mathrm{y}}^{* \mathrm{k}}$ \\
\hline $\mathbf{e}_{1 z}^{\mathrm{k}}$ & $\mathbf{e}_{1 \mathrm{z}}^{\mathrm{k}}$ & $-\mathbf{e}_{2 \mathrm{z}}^{\mathrm{k}}$ & $-\mathbf{e}_{2 z}^{k}$ & $\mathbf{e}_{1 \mathrm{z}}^{\mathrm{k}}$ & $\mathbf{e}_{2 \mathrm{z}}^{* \mathrm{k}}$ & $-\mathbf{e}_{1 \mathrm{z}}^{* \mathrm{k}}$ & $-\mathbf{e}_{1 \mathrm{z}}^{* \mathrm{k}}$ & $\mathbf{e}_{2 \mathrm{z}}^{* \mathrm{k}}$ \\
\hline $\mathbf{e}_{2 \mathrm{x}}^{\mathrm{k}}$ & $\mathbf{e}_{2 \mathrm{x}}^{\mathrm{k}}$ & $\mathbf{e}_{1 \mathrm{x}}^{\mathrm{k}}$ & $-\mathbf{e}_{1 \mathrm{x}}^{\mathrm{k}}$ & $-\mathbf{e}_{2 \mathrm{x}}^{\mathrm{k}}$ & $\mathbf{e}_{1 \mathrm{x}}^{* \mathrm{k}}$ & $\mathbf{e}_{2 \mathrm{x}}^{* \mathrm{k}}$ & $-\mathbf{e}_{2 \mathrm{x}}^{* \mathrm{k}}$ & $-\mathbf{e}_{1 \mathrm{x}}^{* \mathrm{k}}$ \\
\hline $\mathbf{e}_{2 y}^{\mathrm{k}}$ & $\mathbf{e}_{2 \mathrm{y}}^{\mathrm{k}}$ & $-\mathbf{e}_{1 \mathrm{y}}^{\mathrm{k}}$ & $\mathbf{e}_{1 \mathrm{y}}^{\mathrm{k}}$ & $-\mathbf{e}_{2 y}^{\mathrm{k}}$ & $\mathbf{e}_{1 \mathrm{y}}^{* \mathrm{k}}$ & $-\mathbf{e}_{2 \mathrm{y}}^{* \mathrm{k}}$ & $\mathbf{e}_{2 \mathrm{y}}^{* \mathrm{k}}$ & $-\mathbf{e}_{1 \mathrm{y}}^{* \mathrm{k}}$ \\
\hline $\mathbf{e}_{2 z}^{\mathrm{k}}$ & $\mathbf{e}_{2 z}^{k}$ & $-\mathbf{e}_{1 \mathrm{z}}^{\mathrm{k}}$ & $-\mathbf{e}_{1 \mathrm{z}}^{\mathrm{k}}$ & $\mathbf{e}_{2 z}^{\mathrm{k}}$ & $\mathbf{e}_{1 \mathrm{z}}^{* \mathrm{k}}$ & $-\mathbf{e}_{2 \mathrm{z}}^{* \mathrm{k}}$ & $-\mathbf{e}_{2 \mathrm{z}}^{* \mathrm{k}}$ & $\mathbf{e}_{1 \mathrm{z}}^{\mathrm{*k}}$ \\
\hline $\mathbf{e}_{1 \mathrm{x}}^{* \mathrm{k}}$ & $\mathbf{e}_{1 \mathrm{x}}^{* \mathrm{k}}$ & $\mathbf{e}_{2 \mathrm{x}}^{* \mathrm{k}}$ & $-\mathbf{e}_{2 \mathrm{x}}^{* \mathrm{k}}$ & $-\mathbf{e}_{1 \mathrm{x}}^{* \mathrm{k}}$ & $\mathbf{e}_{2 \mathrm{x}}^{\mathrm{k}}$ & $\mathbf{e}_{1 \mathrm{x}}^{\mathrm{k}}$ & $-\mathbf{e}_{1 \mathrm{x}}^{\mathrm{k}}$ & $-\mathbf{e}_{2 \mathrm{x}}^{\mathrm{k}}$ \\
\hline $\mathbf{e}_{1 \mathrm{y}}^{* \mathrm{k}}$ & $\mathbf{e}_{1 \mathrm{y}}^{* \mathrm{k}}$ & $-\mathbf{e}_{2 \mathrm{y}}^{* \mathrm{k}}$ & $\mathbf{e}_{2 \mathrm{y}}^{* \mathrm{k}}$ & $-\mathbf{e}_{1 \mathrm{y}}^{* \mathrm{k}}$ & $\mathbf{e}_{2 y}^{\mathrm{k}}$ & $-\mathbf{e}_{1 \mathrm{y}}^{\mathrm{k}}$ & $\mathbf{e}_{1 \mathrm{y}}^{\mathrm{k}}$ & $-\mathbf{e}_{2 y}^{\mathrm{k}}$ \\
\hline $\mathbf{e}_{1 \mathrm{z}}^{* \mathrm{k}}$ & $\mathbf{e}_{1 \mathrm{z}}^{* \mathrm{k}}$ & $-\mathbf{e}_{2 z}^{* \mathrm{k}}$ & $-\mathbf{e}_{2 \mathrm{z}}^{* \mathrm{k}}$ & $\mathbf{e}_{1 \mathrm{z}}^{* \mathrm{k}}$ & $\mathbf{e}_{2 z}^{k}$ & $-\mathbf{e}_{1 \mathrm{z}}^{\mathrm{k}}$ & $-\mathbf{e}_{1 \mathrm{z}}^{\mathrm{k}}$ & $\mathbf{e}_{2 \mathrm{z}}^{\mathrm{k}}$ \\
\hline $\mathbf{e}_{2 \mathrm{x}}^{* \mathrm{k}}$ & $\mathbf{e}_{2 \mathrm{x}}^{* \mathrm{k}}$ & $\mathbf{e}_{1 \mathrm{x}}^{* \mathrm{k}}$ & $-\mathbf{e}_{1 \mathrm{x}}^{* \mathrm{k}}$ & $-\mathbf{e}_{2 \mathrm{x}}^{* \mathrm{k}}$ & $\mathbf{e}_{1 \mathrm{x}}^{\mathrm{k}}$ & $\mathbf{e}_{2 \mathrm{x}}^{\mathrm{k}}$ & $-\mathbf{e}_{2 \mathrm{x}}^{\mathrm{k}}$ & $-\mathbf{e}_{1 \mathrm{x}}^{\mathrm{k}}$ \\
\hline $\mathbf{e}_{2 \mathrm{y}}^{* \mathrm{k}}$ & $\mathbf{e}_{2 \mathrm{y}}^{* \mathrm{k}}$ & $-\mathbf{e}_{1 \mathrm{y}}^{* \mathrm{k}}$ & $\mathbf{e}_{1 \mathrm{y}}^{* \mathrm{k}}$ & $-\mathbf{e}_{2 \mathrm{y}}^{* \mathrm{k}}$ & $\mathbf{e}_{1 \mathrm{y}}^{\mathrm{k}}$ & $-\mathbf{e}_{2 y}^{k}$ & $\mathbf{e}_{2 \mathrm{y}}^{\mathrm{k}}$ & $-\mathbf{e}_{1 \mathrm{y}}^{\mathrm{k}}$ \\
\hline $\mathbf{e}_{2 \mathrm{z}}^{* \mathrm{k}}$ & $\mathbf{e}_{2 \mathrm{z}}^{* \mathrm{k}}$ & $-\mathbf{e}_{1 \mathrm{z}}^{* \mathrm{k}}$ & $-\mathbf{e}_{1 \mathrm{z}}^{* \mathrm{k}}$ & $\mathbf{e}_{2 \mathrm{z}}^{* \mathrm{k}}$ & $\mathbf{e}_{1 \mathrm{z}}^{\mathrm{k}}$ & $-\mathbf{e}_{2 \mathrm{z}}^{\mathrm{k}}$ & $-\mathbf{e}_{2 \mathrm{z}}^{\mathrm{k}}$ & $\mathbf{e}_{1 \mathrm{z}}^{\mathrm{k}}$ \\
\hline$\chi$ & 12 & 0 & 0 & -4 & 0 & 0 & 0 & 0 \\
\hline
\end{tabular}
operators of the group $\mathrm{M}_{\mathrm{k}}$ on the basis vectors $\mathbf{e}_{\mathrm{j} \alpha}^{\mathrm{k}}$ and $\mathbf{e}_{\mathrm{j} \alpha}^{* \mathrm{k}}$. The action of all the operators of the small co-group $\mathrm{M}_{\mathrm{k}}=\mathrm{G}_{\mathrm{k}}+\mathrm{Ch}_{25} \mathrm{G}_{\mathrm{k}}$ is given in the next table:

The reality criterion gives a value of the sum $\sum_{j} \chi\left(a_{j}^{2}\right)$ equal to 4 for all the irreducible representations of the group $\mathrm{G}_{\mathrm{k}}$. Therefore all the irreducible co-representations of $\mathrm{M}_{\mathrm{k}}$ correspond to case (a). They are given in the next table: 
EPJ Web of Conferences

\begin{tabular}{|l|c|c|c|c|c|c|c|c|}
\hline Ir. co-representation & $\mathrm{h}_{1}$ & $\mathrm{~h}_{2}$ & $\mathrm{~h}_{27}$ & $\mathrm{~h}_{28}$ & $\mathrm{Ch}_{25}$ & $\mathrm{Ch}_{26}$ & $\mathrm{Ch}_{3}$ & $\mathrm{Ch}_{4}$ \\
\hline $\mathrm{c} \tau_{1}^{+}$ & 1 & 1 & 1 & 1 & 1 & 1 & 1 & 1 \\
\hline $\mathrm{c} \tau_{1}^{-}$ & 1 & 1 & 1 & 1 & -1 & -1 & -1 & -1 \\
\hline $\mathrm{c} \tau_{2}^{+}$ & 1 & 1 & -1 & -1 & 1 & 1 & -1 & -1 \\
\hline $\mathrm{c} \tau_{2}^{-}$ & 1 & 1 & -1 & -1 & -1 & -1 & 1 & 1 \\
\hline $\mathrm{c} \tau_{3}^{+}$ & 1 & -1 & 1 & -1 & 1 & -1 & 1 & -1 \\
\hline $\mathrm{c} \tau_{3}^{-}$ & 1 & -1 & 1 & -1 & -1 & 1 & -1 & 1 \\
\hline $\mathrm{c} \tau_{4}^{+}$ & 1 & -1 & -1 & 1 & 1 & -1 & -1 & 1 \\
\hline $\mathrm{c} \tau_{4}^{-}$ & 1 & -1 & -1 & 1 & -1 & 1 & 1 & -1 \\
\hline
\end{tabular}

The decomposition of the natural co-representation into the irreducible co-representations becomes:

$$
\mathrm{c} \Gamma_{\mathrm{k}}=\mathrm{c} \tau_{1}^{+}+\mathrm{c} \tau_{1}^{-}+2 \mathrm{c} \tau_{2}^{+}+2 \mathrm{c} \tau_{2}^{-}+2 \mathrm{c} \tau_{3}^{+}+2 \mathrm{c} \tau_{3}^{-}+\mathrm{c} \tau_{4}^{+}+\mathrm{c} \tau_{4}^{-}
$$

The new basis vectors for each irreducible co-representation are obtained with the projection operators applied to the components $\mathbf{e}_{\mathrm{j}, \alpha}^{\mathrm{k}}$ or $\mathbf{e}_{\mathrm{j}, \alpha}^{* \mathrm{k}}$ :

We get the following vectors:

For co-representation $\mathrm{c} \tau_{1}^{+}$

$$
\mathbf{E}_{1^{+}}=\left(\mathbf{e}_{1 \mathrm{z}}^{\mathrm{k}}-\mathbf{e}_{2 \mathrm{z}}^{\mathrm{k}}\right)-\left(\mathbf{e}_{1 \mathrm{z}}^{* \mathrm{k}}-\mathbf{e}_{2 \mathrm{z}}^{* \mathrm{k}}\right)
$$

which means a sinusoid which propagates along Ox, with the moments along Oz of atoms 1 and 2 equal and opposed to each other as that found with representation analysis.

For co-representation $\tau_{1}^{-}$

$$
\mathbf{E}_{1^{-}}=\left(\mathbf{e}_{1 \mathrm{z}}^{\mathrm{k}}-\mathbf{e}_{2 \mathrm{z}}^{\mathrm{k}}\right)+\left(\mathbf{e}_{1 \mathrm{z}}^{* \mathrm{k}}-\mathbf{e}_{2 \mathrm{z}}^{* \mathrm{k}}\right)
$$

which is the same solution as that found just above, apart from a coefficient $i$ (phase difference of $\pi / 2$ ).

For co-representation $\mathrm{c} \tau_{2}^{+}$

$$
\begin{aligned}
& \mathbf{E}_{2^{+}}^{1}=\left(\mathbf{e}_{1 \mathrm{x}}^{\mathrm{k}}+\mathbf{e}_{2 \mathrm{x}}^{\mathrm{k}}\right)+\left(\mathbf{e}_{1 \mathrm{x}}^{* \mathrm{k}}+\mathbf{e}_{2 \mathrm{x}}^{* \mathrm{k}}\right) \\
& \mathbf{E}_{2^{+}}^{2}=\left(\mathbf{e}_{1 \mathrm{y}}^{\mathrm{k}}-\mathbf{e}_{2 \mathrm{y}}^{\mathrm{k}}\right)-\left(\mathbf{e}_{1 \mathrm{y}}^{* \mathrm{k}}-\mathbf{e}_{2 \mathrm{y}}^{* \mathrm{k}}\right)
\end{aligned}
$$

which represents a modulation which propagates along Ox with components x parallel and components $y$ antiparallel. But now the phase difference between the two components is determined by the symmetry: the two components are in quadrature. There are only two parameters which remain to be determined experimentally, two instead of three : the lengths of the two components.

For co-representation $\mathrm{c} \tau_{2}^{-}$

$$
\begin{aligned}
& \mathbf{E}_{2^{-}}^{1}=\left(\mathbf{e}_{1 \mathrm{x}}^{\mathrm{k}}+\mathbf{e}_{2 \mathrm{x}}^{\mathrm{k}}\right)-\left(\mathbf{e}_{1 \mathrm{x}}^{* \mathrm{k}}+\mathbf{e}_{2 \mathrm{x}}^{* \mathrm{k}}\right) \\
& \mathbf{E}_{2^{-}}^{2}=\left(\mathbf{e}_{1 \mathrm{y}}^{\mathrm{k}}-\mathbf{e}_{2 \mathrm{y}}^{\mathrm{k}}\right)+\left(\mathbf{e}_{1 \mathrm{y}}^{* \mathrm{k}}-\mathbf{e}_{2 \mathrm{y}}^{* \mathrm{k}}\right)
\end{aligned}
$$

which is the same solution as that found above for co-representation $\mathrm{c} \tau_{2}^{+}$apart from an imaginary coefficient

For co-representation $\mathrm{c} \tau_{3}^{+}$

$$
\begin{aligned}
& \mathbf{E}_{3^{+}}^{1}=\left(\mathbf{e}_{1 \mathrm{x}}^{\mathrm{k}}-\mathbf{e}_{2 \mathrm{x}}^{\mathrm{k}}\right)-\left(\mathbf{e}_{1 \mathrm{x}}^{* \mathrm{k}}-\mathbf{e}_{2 \mathrm{x}}^{* \mathrm{k}}\right) \\
& \mathbf{E}_{3^{+}}^{2}=\left(\mathbf{e}_{1 \mathrm{y}}^{\mathrm{k}}+\mathbf{e}_{2 \mathrm{y}}^{\mathrm{k}}\right)+\left(\mathbf{e}_{1 \mathrm{y}}^{* \mathrm{k}}+\mathbf{e}_{2 \mathrm{y}}^{* \mathrm{k}}\right)
\end{aligned}
$$


For co-representation $\mathrm{c}_{3}^{-}$

$$
\begin{aligned}
& \mathbf{E}_{3^{-}}^{1}=\left(\mathbf{e}_{1 \mathrm{x}}^{\mathrm{k}}-\mathbf{e}_{2 \mathrm{x}}^{\mathrm{k}}\right)+\left(\mathbf{e}_{1 \mathrm{x}}^{* \mathrm{k}}-\mathbf{e}_{2 \mathrm{x}}^{* \mathrm{k}}\right) \\
& \mathbf{E}_{3^{-}}^{2}=\left(\mathbf{e}_{1 \mathrm{y}}^{\mathrm{k}}+\mathbf{e}_{2 \mathrm{y}}^{\mathrm{k}}\right)-\left(\mathbf{e}_{1 \mathrm{y}}^{* \mathrm{k}}+\mathbf{e}_{2 \mathrm{y}}^{* \mathrm{k}}\right)
\end{aligned}
$$

For co-representation $\mathrm{c} \tau_{4}^{+}$

$$
\mathbf{E}_{4^{+}}=\left(\mathbf{e}_{1 \mathrm{z}}^{\mathrm{k}}+\mathbf{e}_{2 \mathrm{z}}^{\mathrm{k}}\right)+\left(\mathbf{e}_{1 \mathrm{z}}^{* \mathrm{k}}+\mathbf{e}_{2 \mathrm{z}}^{* \mathrm{k}}\right)
$$

For co-representation $\mathrm{c} \tau_{4}^{-}$

$$
\mathbf{E}_{4^{-}}=\left(\mathbf{e}_{1 \mathrm{z}}^{\mathrm{k}}+\mathbf{e}_{2 \mathrm{z}}^{\mathrm{k}}\right)-\left(\mathbf{e}_{1 \mathrm{z}}^{* \mathrm{k}}+\mathbf{e}_{2 \mathrm{z}}^{* \mathrm{k}}\right)
$$

The magnetic structures for $c \tau_{3}$ and $c \tau_{4}$ are the same as those of $c \tau_{2}$ and $c \tau_{1}$ with a change of sign of the coupling between the atoms 1 and 2 .

The interest of this example lies in the prediction of a $\pi / 2$ phase difference between the $\mathrm{x}$ and $\mathrm{y}$ components of the two chains of moments which modulate along Ox. This phase difference is the result of the Dzialoshinski-Moriya coupling between each moment $\mathbf{m}_{\mathrm{j}}(\mathbf{R})$ and its neighbours $\mathbf{m}_{\mathrm{j}}(\mathbf{R}-\mathbf{a})$ and $\mathbf{m}_{\mathrm{j}}(\mathbf{R}+\mathbf{a})$ along the chain. Let us assume that there is a modulation of the $\mathrm{x}$ component: due to the D-M antisymmetric coupling, the y component will also modulate. For symmetry reasons, the D-M vector is parallel to $\mathrm{Oz}$ and the coupling energy is of the type

$$
\mathrm{F}_{\mathrm{D}-\mathrm{M}}=J\left[\mathrm{~m}_{\mathrm{jx}}(\mathbf{R}-\mathbf{a}) \mathrm{m}_{\mathrm{jy}}(\mathbf{R})-\mathrm{m}_{\mathrm{jx}}(\mathbf{R}+\mathbf{a}) \mathrm{m}_{\mathrm{jy}}(\mathbf{R})\right]=J \mathrm{~m}_{\mathrm{jy}}(\mathbf{R})\left[\mathrm{m}_{\mathrm{jx}}(\mathbf{R}-\mathbf{a})-\mathrm{m}_{\mathrm{jx}}(\mathbf{R}+\mathbf{a})\right]
$$

Therefore the extremum of the y component corresponds to a node of the $\mathrm{x}$ component (when $\mathrm{m}_{\mathrm{jx}}(R)$ varies the faster) and vice versa: the two components are in phase quadrature.

\section{CONCLUSION: CONJUGATION AND TIME INVERSION}

The results thus obtained are, as expected, all compatible with those of the usual representation theory, but, in many cases, they bring more relations between the components of the Fourier components. It would be a pity to neglect this extra information in the treatment of the experimental data.

In simple cases, there are other ways to treat the symmetry operators which transform $\mathbf{k}$ in $-\mathbf{k}$ in the frame of group theory. Reference [9] compares different approaches with and without use of co-representations to find the magnetic structure of $\mathrm{CeAl}_{2}$, a cubic compound with 2 atoms in the asymmetric unit. The method presented in this paper has the advantage to be general. It may be applied easily because the co-representations of all the space groups have been tabulated for any symmetry position of the propagation vector. It can also be implemented in the computer programs which exist already and would permit to find the extra details evoked higher in the search of magnetic structures in large unit cell crystals.

In former publications, co-representations have been used as a consequence of the introduction of the operator "time inversion" $[2,3]$. There is however an ambiguity in defining the time inversion operator. It certainly changes the signs of the magnetic moments as it reverses the direction of the current loops which create the magnetic moments. But, as pointed out by Villain [10], in such cases of classical (and not quantum) moment problems, there are two possibilities to define the time inversion: either as a linear operator or as an antilinear operator. If it is defined as a linear operator, its introduction in the representation theory of magnetic moments does not bring any more information than the usual theory without making use of this time inversion operator, as was shown in reference [11]. If it is antilinear, it leads to the use of the co-representations and the results are exactly the same as those which are obtained with the conjugation operator. We have chosen here to work with the conjugation operator as it is simpler to manipulate (there is no sign change for the magnetic moments) and it is easier to understand its role: it keeps invarient the magnetic energy because the magnetic energy is a real quantity. 
The author expresses his warmest thanks to Jacques Villain who was always open to discussion and who, more than once, put him back on the right track. He wants also to thank Frédéric Bourdarot for a careful and critical reading of this text.

\section{References}

[1] see chapter by J. Rodríguez-Carvajal and F. Bourée

[2] E.F. Bertaut, Journal de Physique, Colloque C1, tome 32 (1971), pages 462-470

[3] J. Rossat Mignod, in "Methods of Experimental Physics", Chap. 20: Magnetic Structures, edited by K. Skold and D.L. Price, Volume 23, pp 69-157, Acad. Press (1987)

[4] J. Schweizer, C. R. Physique 6 (2005) 375-384; corrigendum: C. R. Physique 8 (2007) 823-824

[5] O.V. Kovalev in "Representations of the Crystallographic Space Groups. Irreducible Representations, Induced Representations and Corepresentations", edited by H.T. Stokes and D.M. Hatch, Gordon and Breach Science Publishers (1993)

[6] C.J. Bradley and A.P. Cracknell in "The Mathematical Theory of Symmetry in Solids", Clarendon Press, Oxford (1972)

[7] E.P. Wigner in "Group Theory and its Application to the Quantum Mechanics of Atomic Spectra", Academic Press, New York and London (1959)

[8] F. Lévy private communication

[9] J. Schweizer, J. Villain and A.B. Harris, Eur. Phys. J. Appl. Phys. 38 (2007) 41-47

[10] J. Villain, private communication

[11] Yu. A. Izyumov, V. E. Naish, R. P. Ozerov in "Neutron Diffraction of Magnetic Materials" (1991) Consultants Bureau, New York and London 